\title{
Vegetation feedbacks during drought exacerbate ozone air pollution extremes in Europe
}

Lin, Meiyun; Horowitz, Larry W.; Xie, Yuanyu; Paulot, Fabien; Malyshev, Sergey; Shevliakova, Elena; Finco, Angelo; Gerosa, Giacomo; Kubistin, Dagmar; Pilegaard, Kim

Published in:

Nature Climate Change

Link to article, DOI:

$10.1038 / \mathrm{s} 41558-020-0743-y$

Publication date:

2020

Document Version

Peer reviewed version

Link back to DTU Orbit

Citation (APA):

Lin, M., Horowitz, L. W., Xie, Y., Paulot, F., Malyshev, S., Shevliakova, E., Finco, A., Gerosa, G., Kubistin, D., \& Pilegaard, K. (2020). Vegetation feedbacks during drought exacerbate ozone air pollution extremes in Europe. Nature Climate Change, 10, 444-451. https://doi.org/10.1038/s41558-020-0743-y

\section{General rights}

Copyright and moral rights for the publications made accessible in the public portal are retained by the authors and/or other copyright owners and it is a condition of accessing publications that users recognise and abide by the legal requirements associated with these rights.

- Users may download and print one copy of any publication from the public portal for the purpose of private study or research.

- You may not further distribute the material or use it for any profit-making activity or commercial gain

- You may freely distribute the URL identifying the publication in the public portal 


\title{
Vegetation feedbacks during drought exacerbate ozone air pollution extremes in Europe
}

Meiyun Lin ${ }^{1,2 *}$, Larry W. Horowitz ${ }^{2}$, Yuanyu Xie ${ }^{1,2}$, Fabien Paulot ${ }^{2}$, Sergey Malyshev ${ }^{2}$, Elena Shevliakova ${ }^{2}$, Angelo Finco ${ }^{3}$, Giacomo Gerosa ${ }^{3}$, Dagmar Kubistin ${ }^{4}$, Kim Pilegaard $^{5}$

${ }^{1}$ Program in Atmospheric and Oceanic Sciences, Princeton University, Princeton, NJ 08540, USA

${ }^{2}$ NOAA Geophysical Fluid Dynamics Laboratory, Princeton, NJ 08540, USA

${ }^{3}$ Department of Mathematics and Physics, Catholic University of the Sacred Heart, Via Musei 41, 25121 Brescia, BS, Italy

${ }^{4}$ Deutscher Wetterdienst (DWD), Hohenpeissenberg Meteorological Observatory, Albin

Schwaiger Weg 10, 82383 Hohenpeissenberg, Germany

${ }^{5}$ Department of Environmental Engineering, Technical University of Denmark, 2800 Kgs.

Lyngby, Denmark

Corresponding author: M. Lin (Email: Meiyun.Lin@noaa.gov; Tel: 609-452-6551)

Accepted for publication in Nature Climate Change, February 2020

\begin{abstract}
.
Reducing surface ozone to meet the European Union's target for human health has proven challenging despite stringent controls on ozone precursor emissions over recent decades. The most extreme ozone pollution episodes are linked to heatwaves and droughts, which are increasing in frequency and intensity over Europe, with severe impacts on natural and human systems. Here, we use observations and Earth system model simulations for the period 1960-2018 to show that ecosystem-atmosphere interactions, especially reduced ozone removal by water-stressed vegetation, exacerbate ozone air pollution over Europe. These vegetation feedbacks worsen peak ozone episodes during European mega-droughts, such as the 2003 event, offsetting much of the air quality improvements gained from regional emissions controls. As the frequency of hot and dry summers is expected to increase over the coming decades, this climate penalty could be severe and therefore needs to be considered when designing clean air policy in the European Union.
\end{abstract}

\section{Main [3005 words]}

Ground-level ozone exposure harms human and plant health, especially on hot summer days when pollution from cars and power plants fuels ozone formation. To lessen these impacts, the European Union (EU) has developed legislation to reduce regional ozone precursor emissions from Member States ${ }^{1-4}$. Since 1980, emissions of nitrogen oxides $\left(\mathrm{NO}_{\mathrm{x}}\right)$, the key precursor to ozone formation, leveled off and then declined, after rising for several decades over Europe ${ }^{1,5-8}$. Nevertheless, European surface ozone continued to increase across all seasons, by as much as 10 $\mathrm{ppb}(20 \%)$ in the $1980 \mathrm{~s}$ and $5 \mathrm{ppb}(10 \%)$ in the $1990 \mathrm{~s}^{9,10}$. Although the peak ozone concentrations started to decrease in the $2000 \mathrm{~s}$, the fraction of the urban population (more than $70 \%$ of total population) in Europe exposed to ozone levels exceeding the World Health Organization's air quality guideline (8-hour daily maximum above $100 \mu \mathrm{g} / \mathrm{m}^{3}$ ) remained consistently over $95 \%$ 
(ref. ${ }^{11,12}$ ). Despite decades of research, accurately simulating long-term ozone trends in Europe remains a challenge in various models, including: hindcast simulations forced by observed interannually varying meteorology ${ }^{13-15}$, chemical transport models with time-varying emissions but fixed-year meteorology ${ }^{16,17}$, and chemistry-climate model simulations constrained by historical emissions ${ }^{18,19}$. In particular, little is known about the drivers of the summertime ozone increases observed in the 1980s and 1990s, when ozone precursor emissions were constant or decreasing over Europe and North America and pollution transport from Asia was relatively low ${ }^{20,21}$.

Peak ozone episodes during summer are linked to weather conditions, especially stagnant high-pressure systems, heatwaves, and droughts. Land-atmosphere interactions typically worsen the persistence of such weather extremes in Europe ${ }^{22-27}$. High temperatures accelerate soil drying, and dry soils warm the atmosphere by retaining less water for evapotranspiration ${ }^{28}$. Under drought stress, plants close their stomata to reduce water loss, limiting the uptake of ozone by vegetation (a component of dry deposition) and increasing surface ozone concentrations ${ }^{29,30}$. The impact of such ecosystem-atmosphere interactions on air quality is often overlooked in large-scale atmospheric chemistry models ${ }^{21,31-34}$. These models typically parameterize ozone deposition using a variant of the Wesely (1989) scheme ${ }^{35}$, which does not account for stomatal closure induced by soil drying or rising atmospheric $\mathrm{CO}_{2}$ concentrations ${ }^{30,35,36}$. A few recent models show the importance of including the effects of soil moisture ${ }^{37-41}$ and ozone damage ${ }^{42,43}$ on stomatal uptake, which represents $40-80 \%$ of total ozone deposition ${ }^{30,40}$. Improved understanding of ozone deposition is required to interpret the observed trends of ozone air pollution in Europe and to benefit adaptation and mitigation efforts.

Here we show the slow progress towards improving ozone air quality in Europe can be partly explained by declining rates of ozone removal by water-stressed vegetation in response to climate warming. Ecosystem-atmosphere interactions exacerbate the sensitivity of extreme ozone levels to increasing temperature, i.e., the ozone climate penalty ${ }^{44,45}$, in densely populated regions of Europe, offsetting the benefits from regional precursor emissions controls. Specifically, we investigate the contribution of drought to the climate penalty on ozone extremes over the past six decades, using observations and earth system model simulations with interactive dry deposition $^{40,46}$ and atmospheric chemistry ${ }^{21,47}$ (Methods). In contrast to the widely used Wesely scheme $^{31-35}$ and other empirical approaches ${ }^{36-39,48}$, our dry deposition scheme includes a mechanistic simulation of ozone deposition to vegetation depending on photosynthesis, soil water stress, atmospheric $\mathrm{CO}_{2}$ concentration and vapor pressure deficit ${ }^{40}$ (Methods).

\section{Observed climate penalty on ozone air pollution}

We analyze regionally representative observations at the four Global Atmosphere Watch stations in Europe with the longest continuous surface ozone records: Hohenpeissenberg, Germany; Zugspitze, Germany; Sonnblick, Austria; and Jungfraujoch, Switzerland (Methods). Summertime ozone at these sites correlates strongly with surface air temperature on interannual-to-decadal time scales and has increased rapidly from the 1980s to the early 2000s, with a slope of approximately $5 \mathrm{ppb} \mathrm{K}^{-1}\left(r^{2}=0.6\right.$; Fig.1a and Extended Data Fig.1). The trend of ozone does not mimic that of regional $\mathrm{NO}_{\mathrm{x}}$ emissions, which show little change in the 1980s followed by a sharp decrease to the 1960 level by 2018, broadly consistent with decreases in tropospheric $\mathrm{NO}_{2}$ columns observed from space ${ }^{8}$ (Fig.1b). Similar to $\mathrm{NO}_{\mathrm{x}}$, anthropogenic emissions of other ozone precursors in Europe have also decreased markedly over recent decades ${ }^{11,49}$ (Extended Data Fig.2). The lack of 
significant decreases in ozone during summer despite stringent emissions controls suggests an offsetting effect from climate warming.

Despite a 45\% reduction in regional $\mathrm{NO}_{\mathrm{x}}$ emissions (-67\% for NMVOCs) from 1979 to 2015, little difference is discernable between 1979-1989 and 2001-2015 in the distributions of summertime daily maximum 8-hour average (MDA8) ozone measured at Hohenpeissenberg (Fig.2a). In fact, there is a $5 \%$ increase in the number of days when MDA8 ozone exceeds $60 \mathrm{ppb}\left(120 \mu \mathrm{g} / \mathrm{m}^{3}\right)$, the EU target for human health (not to be exceeded on more than 25 days per year, averaged over three years $)^{2}$. Expanding our analysis to observations at hundreds of sites from the European Monitoring and Evaluation Program (EMEP) operated since 1990, we find a similar lack of change in the ozone distribution between 1990-2000 and 2001-2015 for July, when maximum temperatures typically occur in Europe (Fig.2b). A linear regression of the $95^{\text {th }}$ percentile of MDA8 ozone in July during 1990-2015 supports insignificant trends $(\mathrm{p} \geq 0.05)$ at $88 \%$ of the stations (Extended Data Fig.3). In August, the observed ozone distribution shifted slightly downward in 2001-2015 relative to 1990-2000 (Fig.2c). Nevertheless, the ozone decreases during August in Europe are two times weaker than those over the eastern United States associated with a similar strength of regional emissions controls during this period ${ }^{21}$.

In July 1994, July 2006, and August 2003, much of Europe experienced weekly to monthly temperature anomalies over $5-10{ }^{\circ} \mathrm{C}$ above normal ${ }^{50,51}$, accompanied by severe soil moisture drought ${ }^{25,52,53}$. Deterioration of ozone air quality during these record hot and dry summers manifested as a significant upward shift in the MDA8 ozone distribution (Fig.2b-c). MDA8 ozone exceeded the 60-ppb EU air quality standard on half of site-days during these extreme summers, double to triple the long-term average exceedances. Exposure to high concentrations of ozone aggravates respiratory illness, exacerbating the negative health effects of heat ${ }^{54}$ and contributing to the catastrophic impacts of the 2003 heatwave, which had an estimated death toll of tens of thousands ${ }^{55,56}$. More recently, severe heatwaves and droughts during the summers of 2015 and 2018 caused widespread exceedances of the health limits for ozone air pollution (Extended Data Fig.4).

There has been an increase in heatwave frequency and magnitude over Europe during the last 20 years $^{50,57,58}$. The extent to which climate warming offsets ozone air quality improvements gained from emissions controls has not been quantified unambiguously. A correlation between high surface ozone and high temperatures reflects at least four processes: (1) air stagnation enabling accumulation of local chemical precursors that fuel ozone formation ${ }^{59,60}$; (2) high temperatures leading to thermal decomposition of peroxyacetyl nitrate (PAN), a reservoir for sequestering $\mathrm{NO}_{\mathrm{x}}$ and $\mathrm{HO}_{\mathrm{x}}$ radicals ${ }^{61,62}$; (3) increasing biogenic emissions of ozone precursors ${ }^{63-67}$; (4) drought linked to heatwaves causing reduced stomatal uptake of ozone and its precursors by vegetation $^{29,40,68}$. In particular, the contribution of vegetation feedbacks during drought is poorly understood. Embedding a mechanistic dry deposition scheme in a dynamic vegetation landatmospheric chemistry-climate model (Methods) allows for quantification of these feedbacks.

\section{Reduced ozone removal by water-stressed vegetation}

Long-term ozone deposition flux measurements are sparse, making it difficult to assess year-toyear variability. We examine hourly ozone deposition velocities $\left(\mathrm{V}_{\mathrm{d}, \mathrm{O} 3}\right)$ calculated from ozone 
eddy covariance fluxes and concentrations measured over a Mediterranean Holm Oak forest in Italy during August 2003 versus August 2004, and over a spruce-dominated forest in Denmark during July 1992 versus June 1994 (Methods). Much of the European continent was affected by severe drought in 2003, caused by prolonged rainfall shortages ${ }^{53}$, as illustrated with the Standardized Precipitation-Evapotranspiration Index (SPEI) ${ }^{69}$ integrated over March-August (Fig.3a). Daytime $\mathrm{V}_{\mathrm{d}, \mathrm{O} 3}$ over the Mediterranean forest decreased to $0.1-0.2 \mathrm{~cm} \mathrm{~s}^{-1}$ in August 2003, representing a $70 \%$ reduction from conditions in the wet summer of 2004 (Fig.3b). Similar decreases in daytime $\mathrm{V}_{\mathrm{d}, \mathrm{O} 3}$ were observed over the Danish spruce forest during July 1992, when a heatwave and drought scorched northern Europe (Fig.3d-3e). No substantial changes in leaf area index were measured during dry summers. The GFDL dynamic vegetation land model (LM4.0; Methods) captures the observed $\mathrm{V}_{\mathrm{d}, 03}$ decreases at both sites, attributed to a stomatal response to soil moisture deficits. Further analysis for sites around the globe indicates that this model represents the salient features of observed $\mathrm{V}_{\mathrm{d}, \mathrm{O} 3}$ over forests, croplands, and pastures, including their spatial, seasonal, and interannual variability associated with drought stress ${ }^{40}$.

Using LM4.0 driven by observation-based atmospheric forcings ${ }^{70}$, we examine how ozone uptake by vegetation has evolved with climate over the past half century (Fig.4). We focus on summertime $\mathrm{V}_{\mathrm{d}, \mathrm{O} 3}$ in the land area bounded by $5^{\circ} \mathrm{W}-25^{\circ} \mathrm{E}$ and $40^{\circ}-55^{\circ} \mathrm{N}$, which was most affected by the 2003 drought. Summertime $\mathrm{V}_{\mathrm{d}, \mathrm{O} 3}$ to natural and secondary vegetation ( $\sim 50 \%$ of the land area) in this region varies strongly on interannual-to-decadal time scales, correlating with temperatures and drought events (Fig.4a-4b). European summer heatwaves are typically linked to soil moisture droughts, although the onset, evolution and spatial extent of each drought varies ${ }^{22,24,53}$. Both longlived (March-August SPEI < -1) and short-lived (June-August SPEI < -1) droughts can cause reductions in $\mathrm{V}_{\mathrm{d}, \mathrm{O} 3}$. Unlike the prolonged 2003 drought event, drought conditions in July 1994 and July 2006 set in quickly and were centered over northwestern Europe (Extended Data Fig.5). The model-simulated $\mathrm{V}_{\mathrm{d}, \mathrm{O} 3}$ decreases in July 1994 and 2006 are comparable to those in August 2003 centered over western Europe (Fig.4c-4e). There has been a strong regional warming trend over Europe since 1980 (Fig.4a), accompanied by a drying trend in Mediterranean Europe ${ }^{53,71-74}$. Our model simulates declining ozone deposition velocities from the 1980 s to the 2000 s $(-12 \%$ over 20 years), reflecting primarily the limitation of stomatal conductance under soil drying, not changes in land use or leaf area index (Extended Data Figs.6-7). The $\mathrm{V}_{\mathrm{d}, \mathrm{O} 3}$ decreases are largest in droughtstressed forests and smaller over pastures or croplands. While increasing atmospheric $\mathrm{CO}_{2}$ concentrations cause reduced stomatal conductance in the late $21^{\text {st }}$ century in climate models ${ }^{75}$, we find the $\mathrm{CO}_{2}$ effects have not yet emerged during our study period (Methods).

\section{Ecosystem-atmosphere interactions worsen ozone extremes}

We next investigate the extent to which model-simulated changes in ozone deposition velocities have influenced observed surface ozone trends and extremes over Europe. We conduct atmospheric chemistry-climate model hindcast simulations from 1960 to 2015, designed to isolate the response of surface ozone to changes in deposition velocities, anthropogenic emissions of ozone precursors, and meteorology (Methods). With $\mathrm{V}_{\mathrm{d}, \mathrm{O} 3}$ fixed at 1960 levels, the FIXDEPV simulation underestimates observed ozone anomalies in dry summers (e.g., 1994, 2003, 2006) by 10-15 ppb (blue curves in Figs.5a-b). With $\mathrm{V}_{\mathrm{d}, \mathrm{O} 3}$ varying with climate and vegetation state, the IAVDEPV model (red) improves the simulations of high-ozone anomalies and better captures 
observed ozone increases from the 1980s to the 2000s. Year-to-year correlations of ozone with observations increase from $0.46-0.52$ for FIXDEPV to $0.56-0.62$ for IAVDEPV.

Reduced ozone removal by water-stressed vegetation worsens the most severe ozone pollution events, causing an upward shift in the probability distribution of surface ozone during the recordhot summers of July 1994, August 2003, and July 2006 (Fig.5c). Accounting for the limitation in ozone uptake by drought-stressed vegetation, the distribution of surface ozone in IAVDEPV shifts towards that in observations, with a three-fold increase in events above $80 \mathrm{ppb}$ (from $4 \%$ in FIXDEPV to $14 \%$ in IAVDEPV, compared with $12 \%$ in observations). The $95^{\text {th }}$ percentile (q95) of MDA8 ozone in IAVDEPV matches well the observed value, increasing by $8 \mathrm{ppb}$ relative to FIXDEPV. There are also increases in the standard deviation $(\sigma)$ of MDA8 ozone, reflecting stronger day-to-day variability in ozone air pollution associated with drought-vegetation interactions.

With time-varying $\mathrm{V}_{\mathrm{d}, \mathrm{O} 3}$ but fixed-1980 high anthropogenic emissions, the IAVDEPV_FIXEM experiment isolates the role of climate change in polluted environments. Surface ozone increases are simulated over 1960-1980 in the two experiments with anthropogenic emissions varying (FIXDEPV and IAVDEPV), but not in the experiment with constant emissions (IAVDEPV_FIXEM), indicating that increasing ozone before 1980 is primarily driven by rising regional emissions of ozone precursors (Fig.5a-b). Since 1980, however, IAVDEPV_FIXEM indicates that climate variations dominate the observed interannual-to-decadal variability in ozone air pollution $\left(\mathrm{r}^{2}=0.52-0.62\right)$. In the absence of emissions controls, the $95^{\text {th }}$ percentile MDA8 ozone in July would have increased by $0.3-0.5 \mathrm{ppb} \mathrm{yr}^{-1}$ during $1979-2015$ and by $0.4-0.8 \mathrm{ppb}^{-1} \mathrm{yr}^{-1}$ dung 1990-2015 over central Europe, consistent with an increase in the frequency of warm days over this region (Extended Data Figs.8a-9a). The temperature-driven increase in biogenic isoprene emissions ( $\sim 1 \% \mathrm{yr}^{-1}$; see Extended Data Fig.2d and Methods) may contribute to the modelled ozone climate penalty. This climate penalty offsets air quality improvements gained from regional emissions controls, leading to little change in the observed ozone distribution in July over recent decades (Fig.2b). In August, a shift in anticyclonic circulation patterns towards central Europe ${ }^{58}$ likely augments the effects of emissions reductions on ozone decreases over the United Kingdom (Extended Data Figs.3, 8b, and 9b).

Rising Asian anthropogenic emissions and global methane concentrations have been implicated in increasing background ozone over Europe ${ }^{10,76}$. Sensitivity simulations (Methods) show that increases in Asian emissions of ozone precursors and in global methane abundance from the 1980s to the 2000s increase free tropospheric ozone measured at Zugspitze ( $\sim 2 \mathrm{ppb})$, but the impact in surface air at Hohenpeissenberg during summer is of minor importance $(<1 \mathrm{ppb})$, in contrast to the dominant role of the climate-driven trends ( $\sim 5$ ppb; Extended Data Fig.10). Warmer temperatures have also led to deeper mixed layers over recent decades ${ }^{77}$, facilitating mixing of surface pollution to alpine sites. While wildfire outbreaks in hot and dry summers worsen particulate air quality, e.g., during the 2010 Russian heatwave ${ }^{78}$, they are not the primary driver of ozone enhancements during hot summers ${ }^{21}$. The buildup of ozone produced from regional emissions under stagnant conditions, combined with reduced removal by water-stressed vegetation, contributes most to deterioration of summertime ozone air quality in Europe. 
Figure 6 further stresses the earth system feedbacks on ozone extremes across Europe using the ozone-temperature regression slope, i.e., the climate penalty factor ${ }^{44,45}$. We apply quantile regression $^{79}$ to observed daily maximum surface temperature and observed daily MDA8 ozone gridded at $0.5^{\circ}$ resolution to identify the climate penalty on extreme pollution levels. The statistical analysis is performed using observations during two emission regimes: 1990-2000 versus 20012018. The observed climate penalty factor is stronger at higher pollution levels and over densely populated regions, such as England, Belgium, the Netherlands, northern France, western Germany and northern Italy (Fig.6a). In these regions, the climate penalty factor is $2.5-3.5 \mathrm{ppb} \mathrm{K}^{-1}$ for the median ozone level, increasing to $3.5-4.5 \mathrm{pp} \mathrm{K}^{-1}$ for the $95^{\text {th }}$ percentile ozone level under 20012018 emission conditions and to $4.0-5.5 \mathrm{ppb} \mathrm{K}^{-1}$ under the greater emission conditions in 19902000.

The FIXDEPV model with constant $\mathrm{V}_{\mathrm{d}, \mathrm{O} 3}$ underestimates the observed climate penalty factor across the entire ozone distribution (Fig.6b). Accounting for reduced ozone uptake by vegetation, the simulated climate penalty factor in IAVDEPV increases by as much as $20-30 \%$ relative to FIXDEPV, reducing mean biases against observations by $14 \%$ (Fig.6c). The model accounting for vegetation feedbacks but under 1980 high-emission conditions best matches the observed climate penalty for extreme ozone (mean biases $= \pm 7 \%$; Fig.6d). The observed climate penalty estimates fall between the IAVDEPV and IAVDEPV_FIXEM experiments. The biases may reflect a combination of differences in the spatial scales of observations and simulations, and uncertainties in natural and anthropogenic emissions of ozone precursors in the model (Methods). For instance, heatwaves may result in increased electricity demand for air conditioner use, thereby increasing emissions of ozone precursors from power generation ${ }^{80}$, while our models do not account for such transient fluctuations in anthropogenic emissions.

Missing or insufficient treatment of climate feedbacks on ozone may explain why previous models underestimate the observed European ozone increases in the 1980s, while showing an excessive response to regional emissions reductions over the last decade ${ }^{16,19,40}$. Most studies argue that the effect of climate change on ozone in polluted environments is much smaller than the effect of regional emission controls ${ }^{60}$, but they do not account for the ecosystem-atmosphere interactions discussed here. To gauge this effect, future research should address model ability to simulate the observed ozone-temperature relationship, the drought-temperature link, and associated earth system feedbacks. Reduced ozone uptake by plants was also observed during recent North American droughts ${ }^{40,68}$ and simulated over semi-arid regions of Asia $^{40}$. Accounting for vegetation feedbacks is central to determining the susceptibility to extreme pollution events in future climate, not only in Europe but also over other populated mid-latitude regions.

\section{Implications for air quality policy}

Our study highlights an under-appreciated "climate penalty" feedback mechanism - namely, substantial reductions of ozone uptake by water-stressed vegetation - as a missing piece to the puzzle of why European ozone pollution episodes have not decreased in recent decades, despite marked reductions in regional emissions of ozone precursors due to regulatory changes. The European Commission adopted a Clean Air Policy Package in 2013, aiming to achieve compliance with existing air quality standards by 2020, and a revised National Emission Ceilings Directive to bring down emissions by 2030 (ref. 3,4). The Directive sets $42 \%$ reduction commitments for total 
$\mathrm{NO}_{\mathrm{x}}$ emissions from EU Member States by 2020 and $63 \%$ by the 2030s, relative to the 2005 level. The European Commission recently estimated that the 2020 reduction commitments have been achieved at the EU level, leading to a remarkable reduction in particulate matter ${ }^{81}$. However, a similar improvement has not occurred in ozone air quality, with 18 Member States still recording concentrations above the EU limit for human health ${ }^{81}$, inconsistent with the goal to achieve compliance by 2020 . While emissions reductions accomplished through current legislation have partially counteracted the ozone climate penalty over the last decade, even stronger emissions controls are required to meet the targeted level of ozone air quality by 2030. Anthropogenic warming will bring higher heatwave temperatures and drier soils to Europe over the coming decades ${ }^{26,27,57}$. As events like the 2003 drought are projected to become twice as frequent under $3 \mathrm{~K}$ of warming relative to $1.5 \mathrm{~K}$ of warming ${ }^{27}$, effective emissions policies for Europe must consider the ozone climate penalty.

\section{References:}

1 Vestreng, V. et al. Evolution of NOx emissions in Europe with focus on road transport control measures. Atmos. Chem. Phys. 9, 1503-1520, doi:10.5194/acp-9-1503-2009 (2009).

2 European Union. Directive 2008/50/EC of the European Parliament and of the Council of 21 May 2008 on ambient air quality and cleaner air for Europe (OJL 152, 11.6.2008, p. 144) (http://eur-lex.europa.eu/LexUriServ/LexUriServ.do?uri=OJ:L:2008:152:0001:0044:EN:PDF) (2008).

3 European Commission. Communication from the Commission to the Council, the European Parliament, the European Economic and Social Committee and the Committee of the Regions - A Clean Air Programme for Europe, COM (2013) 918 final (http://eurlex.europa.eu/legal-content/EN/TXT/PDF/?uri=CELEX:52013DC0918\&from=EN)(2013).

4 European Union. Directive 2016/2284/EC of the European Parliament and of the Council of 14 December 2016 on the reduction of national emissions of certain atmospheric pollutants, amending Directive 2003/35/EC and repealing Directive 2001/81/EC (OJL 344, 17.12.2016, p. 1-31) (http://eur-lex.europa.eu/legalcontent/EN/TXT/?uri=uriserv\%3AOJ.L_.2016.344.01.0001.01.ENG) (2016).

5 Granier, C. et al. Evolution of anthropogenic and biomass burning emissions of air pollutants at global and regional scales during the 1980-2010 period. Climatic Change 109, 163-190, doi:10.1007/s10584-011-0154-1 (2011).

6 Monks, P. S. et al. Tropospheric ozone and its precursors from the urban to the global scale from air quality to short-lived climate forcer. Atmos. Chem. Phys. 15, 8889-8973, doi:10.5194/acp-15-8889-2015 (2015).

7 Hoesly, R. M. et al. Historical (1750-2014) anthropogenic emissions of reactive gases and aerosols from the Community Emissions Data System (CEDS). Geosci. Model Dev. 11, 369-408, doi:10.5194/gmd-11-369-2018 (2018).

8 Georgoulias, A. K., van der A, R. J., Stammes, P., Boersma, K. F. \& Eskes, H. J. Trends and trend reversal detection in 2 decades of tropospheric NO2 satellite observations. Atmos. Chem. Phys. 19, 6269-6294, doi:10.5194/acp-19-6269-2019 (2019).

9 Logan, J. A. et al. Changes in ozone over Europe: Analysis of ozone measurements from sondes, regular aircraft (MOZAIC) and alpine surface sites. J. Geophys. Res. 117, doi:10.1029/2011jd016952 (2012). 
10 Parrish, D. D. et al. Long-term changes in lower tropospheric baseline ozone concentrations at northern mid-latitudes. Atmos. Chem. Phys. 12, 11485-11504, doi:10.5194/acp-12-11485-2012 (2012).

11 European Environment Agency. Air quality in Europe - 2018 report, EEA Report No 12/2018, ISSN 1977-8449 (https://www.eea.europa.eu/publications/air-quality-in-europe2018) (2018).

12 European Environment Agency. Exceedance of air quality standards in urban areas (CSI 004). (https://www.eea.europa.eu/data-and-maps/indicators/exceedance-of-air-qualitylimit-3/assessment-5). (2019).

13 Lelieveld, J. \& Dentener, F. J. What controls tropospheric ozone? J. Geophys. Res. 105, 3531-3551, doi:10.1029/1999jd901011 (2000).

14 Koumoutsaris, S. \& Bey, I. Can a global model reproduce observed trends in summertime surface ozone levels? Atmos. Chem. Phys. 12, 6983-6998, doi:10.5194/acp-12-6983-2012 (2012).

15 Colette, A. et al. Air quality trends in Europe over the past decade: a first multi- model assessment. Atmos. Chem. Phys. 11, 11657-11678, doi:10.5194/acp-11-11657-2011 (2011).

16 Fusco, A. C. \& Logan, J. A. Analysis of 1970-1995 trends in tropospheric ozone at Northern Hemisphere midlatitudes with the GEOS-CHEM model. J. Geophys. Res. 108, doi:10.1029/2002jd002742 (2003).

17 Wild, O. et al. Modelling future changes in surface ozone: a parameterized approach Atmos. Chem. Phys. 12, 2037-2054, doi:10.5194/acp-12-2037-2012 (2012).

18 Lamarque, J. F. et al. Historical (1850-2000) gridded anthropogenic and biomass burning emissions of reactive gases and aerosols: methodology and application. Atmos. Chem. Phys. 10, 7017-7039, doi:10.5194/acp-10-7017-2010 (2010).

19 Parrish, D. D. et al. Long-term changes in lower tropospheric baseline ozone concentrations: Comparing chemistry-climate models and observations at northern midlatitudes. J. Geophys. Res. 119, 5719-5736, doi:10.1002/2013JD021435 (2014).

20 Lin, M. et al. Revisiting the evidence of increasing springtime ozone mixing ratios in the free troposphere over western North America. Geophys. Res. Lett. 42, 8719-8728, doi:10.1002/2015GL065311 (2015).

21 Lin, M., Horowitz, L. W., Payton, R., Fiore, A. M. \& Tonnesen, G. US surface ozone trends and extremes from 1980 to 2014: Quantifying the roles of rising Asian emissions, domestic controls, wildfires, and climate. Atmos. Chem. Phys. 17, 2943-2970, doi:10.5194/acp-17-2943-2017 (2017).

22 Fischer, E. M., Seneviratne, S. I., Luthi, D. \& Schar, C. Contribution of land-atmosphere coupling to recent European summer heat waves. Geophys. Res. Lett. 34, doi:10.1029/2006gl029068 (2007).

23 Seneviratne, S. I., Luthi, D., Litschi, M. \& Schar, C. Land-atmosphere coupling and climate change in Europe. Nature 443, 205-209, doi:10.1038/nature05095 (2006).

24 Hirschi, M. et al. Observational evidence for soil-moisture impact on hot extremes in southeastern Europe. Nat. Geosci. 4, 17-21, doi:10.1038/Ngeo1032 (2011).

25 Miralles, D. G., Teuling, A. J., van Heerwaarden, C. C. \& de Arellano, J. V. G. Megaheatwave temperatures due to combined soil desiccation and atmospheric heat accumulation. Nat. Geosci. 7, 345-349, doi:10.1038/Ngeo2141 (2014). 
26 Rasmijn, L. M. et al. Future equivalent of 2010 Russian heatwave intensified by weakening soil moisture constraints. Nat Clim Change 8, 381-385, doi:10.1038/s41558018-0114-0 (2018).

27 Samaniego, L. et al. Anthropogenic warming exacerbates European soil moisture droughts. Nat Clim Change 8, 421-426, doi:10.1038/s41558-018-0138-5 (2018).

28 Teuling, A. J. CLIMATE HYDROLOGY: A hot future for European droughts. Nat Clim Change 8, 364-365, doi:10.1038/s41558-018-0154-5 (2018).

29 Gerosa, G. et al. Comparison of seasonal variations of ozone exposure and fluxes in a Mediterranean Holm oak forest between the exceptionally dry 2003 and the following year. Environ. Pollut. 157, 1737-1744, doi:10.1016/j.envpol.2007.11.025 (2009).

30 Fowler, D. et al. Atmospheric composition change: Ecosystems-Atmosphere interactions. Atmos. Environ. 43, 5193-5267, doi:10.1016/j.atmosenv.2009.07.068 (2009).

31 Rydsaa, J. H., Stordal, F., Gerosa, G., Finco, A. \& Hodnebrog, O. Evaluating stomatal ozone fluxes in WRF-Chem: Comparing ozone uptake in Mediterranean ecosystems. Atmos. Environ. 143, 237-248, doi:10.1016/j.atmosenv.2016.08.057 (2016).

32 Hardacre, C., Wild, O. \& Emberson, L. An evaluation of ozone dry deposition in global scale chemistry climate models. Atmos. Chem. Phys. 15, 6419-6436, doi:10.5194/acp-156419-2015 (2015).

33 Silva, S. J. \& Heald, C. L. Investigating Dry Deposition of Ozone to Vegetation. J. Geophys. Res.-Atmos. 123, 559-573, doi:10.1002/2017jd027278 (2018).

34 Morgenstern, O. et al. Review of the global models used within phase 1 of the ChemistryClimate Model Initiative (CCMI). Geosci Model Dev 10, 639-671, doi:10.5194/gmd-10639-2017 (2017).

35 Wesely, M. L. Parameterization of surface resistances to gaseous dry deposition in regional-scale numerical models. Atmos. Environ. 23, 1293-1304, doi:10.1016/00046981(89)90153-4 (1989).

36 Kavassalis, S. C. \& Murphy, J. G. Understanding ozone-meteorology correlations: A role for dry deposition. Geophys. Res. Lett. 44, 2922-2931, doi:10.1002/2016g1071791 (2017).

37 Andersson, C. \& Engardt, M. European ozone in a future climate: Importance of changes in dry deposition and isoprene emissions. J. Geophys. Res.-Atmos. 115, doi:10.1029/2008jd011690 (2010).

38 Emberson, L. D., Kitwiroon, N., Beevers, S., Buker, P. \& Cinderby, S. Scorched Earth: how will changes in the strength of the vegetation sink to ozone deposition affect human health and ecosystems? Atmos. Chem. Phys. 13, 6741-6755, doi:10.5194/acp-13-67412013 (2013).

39 Huang, L., McDonald-Buller, E. C., McGaughey, G., Kimura, Y. \& Allen, D. T. The impact of drought on ozone dry deposition over eastern Texas. Atmos. Environ. 127, 176186, doi:10.1016/j.atmosenv.2015.12.022 (2016).

40 Lin, M. et al. Sensitivity of ozone dry deposition to ecosystem-atmosphere interactions: A critical appraisal of observations and simulations. Global Biogeochem. Cycles 33, 1264 1288, doi:10.1029/2018GB006157 (2019).

41 Clifton, O. E., Fiore, A. M., Munger, J. W. \& Wehr, R. Spatiotemporal controls on observed daytime ozone deposition velocity over northeastern U.S. forests during summer. J. Geophys. Res. - Atmos. 124, 5612-5628, doi:10.1029/2018JD029073 (2019). 
42 Lombardozzi, D., Levis, S., Bonan, G., Hess, P. G. \& Sparks, J. P. The Influence of Chronic Ozone Exposure on Global Carbon and Water Cycles. J. Clim. 28, 292-305, doi:10.1175/Jcli-D-14-00223.1 (2015).

43 Sadiq, M., Tai, A. P. K., Lombardozzi, D. \& Martin, M. V. Effects of ozone-vegetation coupling on surface ozone air quality via biogeochemical and meteorological feedbacks. Atmos. Chem. Phys. 17, 3055-3066, doi:10.5194/acp-17-3055-2017 (2017).

44 Bloomer, B. J., Stehr, J. W., Piety, C. A., Salawitch, R. J. \& Dickerson, R. R. Observed relationships of ozone air pollution with temperature and emissions. Geophys. Res. Lett. 36, doi:10.1029/2009g1037308 (2009).

45 Rasmussen, D. J. et al. Surface ozone-temperature relationships in the eastern US: A monthly climatology for evaluating chemistry-climate models. Atmos. Environ. 47, 142153, doi:10.1016/j.atmosenv.2011.11.021 (2012).

46 Paulot, F. et al. Representing sub-grid scale variations in nitrogen deposition associated with land use in a global Earth System Model: implications for present and future nitrogen deposition fluxes over North America. Atmos. Chem. Phys. 18, 17963-17978, doi:10.5194/acp-18-17963-2018 (2018).

47 Lin, M., Horowitz, L. W., Oltmans, S. J., Fiore, A. M. \& Fan, S. Tropospheric ozone trends at Mauna Loa Observatory tied to decadal climate variability. Nat. Geosci. 7, 136-143, doi:10.1038/ngeo2066 (2014).

48 Jarvis, P. G. Interpretation of Variations in Leaf Water Potential and Stomatal Conductance Found in Canopies in Field. Philos T Roy Soc B 273, 593-610, doi:10.1098/rstb.1976.0035 (1976).

49 Schneidemesser, E. v., Monks, P. S. \& Plass-Duelmer, C. Global comparison of VOC and CO observations in urban areas. Atmos. Environ. 44, 5053-5064 (2010).

50 Barriopedro, D., Fischer, E. M., Luterbacher, J., Trigo, R. \& Garcia-Herrera, R. The Hot Summer of 2010: Redrawing the Temperature Record Map of Europe. Science 332, 220224, doi:10.1126/science.1201224 (2011).

51 Russo, S., Sillmann, J. \& Fischer, E. M. Top ten European heatwaves since 1950 and their occurrence in the coming decades. Environ. Res. Lett. 10, doi:10.1088/17489326/10/12/124003 (2015).

52 Fischer, E. M., Seneviratne, S. I., Vidale, P. L., Luthi, D. \& Schar, C. Soil moisture Atmosphere interactions during the 2003 European summer heat wave. J. Clim. 20, 50815099, doi:10.1175/Jcli4288.1 (2007).

53 Sheffield, J. \& Wood, E. F. Drought: Past problems and future scenarios. 140 (Earthscan, 2011).

54 Mora, C. et al. Global risk of deadly heat. Nat Clim Change 7, 501- 506, doi:10.1038/Nclimate3322 (2017).

55 Robine, J. M. et al. Death toll exceeded 70,000 in Europe during the summer of 2003. $\mathrm{Cr}$ Biol 331, 171-178, doi:10.1016/j.crvi.2007.12.001 (2008).

56 Dear, K., Ranmuthugala, G., Kjellstrom, T., Skinner, C. \& Hanigan, I. Effects of temperature and ozone on daily mortality during the August 2003 heat wave in France. Arch Environ Occup H 60, 205-212, doi:Doi 10.3200/Aeoh.60.4.205-212 (2005).

57 Christidis, N., Jones, G. S. \& Stott, P. A. Dramatically increasing chance of extremely hot summers since the 2003 European heatwave. Nat Clim Change 5, 46-50, doi:10.1038/Nclimate2468 (2015). 
58 Horton, D. E. et al. Contribution of changes in atmospheric circulation patterns to extreme temperature trends. Nature 522, 465-469, doi:10.1038/nature14550 (2015).

59 Jacob, D. J. \& Winner, D. A. Effect of climate change on air quality. Atmos. Environ. 43, 51-63, doi:10.1016/j.atmosenv.2008.09.051 (2009).

60 Fiore, A. M., Naik, V. \& Leibensperger, E. M. Air Quality and Climate Connections. J. Air \& Waste Manage. Assoc. 65, 645-685, doi:10.1080/10962247.2015.1040526 (2015).

61 Sillman, S. \& Samson, F. J. Impact of Temperature on Oxidant Photochemistry in Urban, Polluted Rural and Remote Environments. J. Geophys. Res.-Atmos. 100, 11497-11508, doi:Doi 10.1029/94jd02146 (1995).

62 Pusede, S. E., Steiner, A. L. \& Cohen, R. C. Temperature and Recent Trends in the Chemistry of Continental Surface Ozone. Chem. Rev. 115, 3898-3918, doi:10.1021/cr5006815 (2015).

63 Guenther, A. B. et al. The Model of Emissions of Gases and Aerosols from Nature version 2.1 (MEGAN2.1): an extended and updated framework for modeling biogenic emissions. Geosci Model Dev 5, 1471-1492, doi:10.5194/gmd-5-1471-2012 (2012).

64 Yienger, J. J. \& Levy, H. Empirical-Model of Global Soil-Biogenic NOx Emissions. J. Geophys. Res.-Atmos. 100, 11447-11464, doi:Doi 10.1029/95jd00370 (1995).

65 Hudman, R. C., Russell, A. R., Valin, L. C. \& Cohen, R. C. Interannual variability in soil nitric oxide emissions over the United States as viewed from space. Atmos. Chem. Phys. 10, 9943-9952, doi:10.5194/acp-10-9943-2010 (2010).

66 Oikawa, P. Y. et al. Unusually high soil nitrogen oxide emissions influence air quality in a high-temperature agricultural region. Nat. Commun. 6, doi:10.1038/ncomms9753 (2015).

67 Jaffe, D. \& Wigder, N. L. Ozone production from wildfires: A critical review. Atmos. Environ. 51, 1-10, doi:10.1016/j.atmosenv.2011.11.063 (2012).

68 Demetillo, M. A. G. et al. Observing Severe Drought Influences on Ozone Air Pollution in California. Environmental Science \& Technology 53, 4695-4706, doi:10.1021/acs.est.8b04852 (2019).

69 Begueria, S., Vicente-Serrano, S. M., Reig, F. \& Latorre, B. Standardized precipitation evapotranspiration index (SPEI) revisited: parameter fitting, evapotranspiration models, tools, datasets and drought monitoring. Int. J. Clim. 34, 3001-3023, doi:10.1002/joc.3887 (2014).

70 Sheffield, J., Goteti, G. \& Wood, E. F. Development of a 50-year high-resolution global dataset of meteorological forcings for land surface modeling. J. Clim. 19, 3088-3111, doi:10.1175/Jcli3790.1 (2006).

71 Hoerling, M. et al. On the Increased Frequency of Mediterranean Drought. J. Clim. 25, 2146-2161, doi:10.1175/Jcli-D-11-00296.1 (2012).

72 Seager, R. et al. Climate Variability and Change of Mediterranean-Type Climates. J. Clim. 32, 2887-2915, doi:10.1175/Jcli-D-18-0472.1 (2019).

73 Dai, A. G. Increasing drought under global warming in observations and models. Nat Clim Change 3, 52-58, doi:10.1038/Nclimate1811 (2013).

74 Sheffield, J., Wood, E. F. \& Roderick, M. L. Little change in global drought over the past 60 years. Nature 491, 435-+, doi:10.1038/nature11575 (2012).

75 Milly, P. C. D. \& Dunne, K. A. Potential evapotranspiration and continental drying. Nat Clim Change 6, 946-949, doi:10.1038/nclimate3046 (2016). 
76 Derwent, R. G., Simmonds, P. G., Manning, A. J. \& Spain, T. G. Trends over a 20-year period from 1987 to 2007 in surface ozone at the atmospheric research station, Mace Head, Ireland. Atmos. Environ. 41, 9091-9098, doi:10.1016/j.atmosenv.2007.08.008 (2007).

77 Zhang, Y. H., Seidel, D. J. \& Zhang, S. D. Trends in Planetary Boundary Layer Height over Europe. J. Clim. 26, 10071-10076, doi:10.1175/Jcli-D-13-00108.1 (2013).

78 Konovalov, I. B., Beekmann, M., Kuznetsova, I. N., Yurova, A. \& Zvyagintsev, A. M. Atmospheric impacts of the 2010 Russian wildfires: integrating modelling and measurements of an extreme air pollution episode in the Moscow region. Atmos. Chem. Phys. 11, 10031-10056, doi:10.5194/acp-11-10031-2011 (2011).

79 Porter, W. C., Heald, C. L., Cooley, D. \& Russell, B. Investigating the observed sensitivities of air-quality extremes to meteorological drivers via quantile regression. Atmos. Chem. Phys. 15, 10349-10366, doi:10.5194/acp-15-10349-2015 (2015).

80 U.S. Department of Energy. Climate Change and the U.S. Energy Sector: Regional Vulnerabilities and Resilience Solutions, https://www.energy.gov/sites/prod/files/2015/10/f27/Regional_Climate_Vulnerabilities_an d_Resilience_Solutions_0.pdf(2015).

81 European Commission. Report from the Commission to the European Parliament, the European Economic and Social Committee and the Committee of the Regions - "The First Clean Air Outlook", COM 446 final (http://ec.europa.eu/environment/air/pdf/clean_air_outlook.pdf) (2018).

\section{Methods.}

Surface ozone observations. Surface ozone measurements are obtained from Hohenpeissenberg, Germany (1971-2018; 985 m altitude); Zugspitze, Germany (1978-2010; $2962 \mathrm{~m}$ altitude); Sonnblick, Austria (1994-2018; 3106 m altitude); and Jungfraujoch, Switzerland (1996-2018; $3580 \mathrm{~m}$ altitude). Multi-platform, cross-site consistency analyses indicate that the observed ozone changes at these sites are representative of regional-scale conditions over Europe ${ }^{9,10}$. Apparently uncertain data at Sonnblick and Jungfraujoch for the earlier years ${ }^{9}$ are removed from our analysis. Hohenpeissenberg data in 1983 are not representative of regional conditions and thus are removed. We additionally draw upon measurements at hundreds of rural sites from the European Monitoring and Evaluation Program (EMEP) operated since 1990 (https://projects.nilu.no/CCC/emepdata.html) as well as data at thousands of urban and rural sites from the densely distributed regulatory monitoring networks available since 2000 (http://discomap.eea.europa.eu/map/fme/AirQualityExport.htm). EMEP data at individual sites are used in Fig.1, Fig.2, Fig.5 and Extended Data Fig.3. Data from EMEP and the regulatory networks (including those at urban sites) are averaged over a $0.5^{\circ} \times 0.5^{\circ}$ grid for calculating the ozone climate penalty factors (Fig.6a). Most original data are processed from the Tropospheric Ozone Assessment Report (TOAR) database ${ }^{82}$. The daily maximum 8-hour average (MDA8) value is calculated for each day and each monitor. We apply a $75 \%$ data coverage criterion as recommended by TOAR: a daily MDA8 value is considered valid if at least 18 out of the 24 running 8-hour averages are valid. The trends of ozone can vary substantially over different time periods due to large interannual variability ${ }^{47}$. To ensure comparison across sites over the same time period, we require that at least $75 \%$ of the years have valid data when calculating the MDA 8 ozone trends at individual sites (Extended Data Fig.3). For the quantile regression of daily observations in July and August, we apply a 50\% data coverage criterion (sample size $\mathrm{N}>341$ for 1990-2000 and $\mathrm{N}>558$ for 2001-2018) in order to include observations over eastern Europe (Fig.6a). Note that most sites in western Europe have data coverage greater than $75 \%$. 
Tropospheric $\mathrm{NO}_{2}$ from satellites. Satellite-retrieved tropospheric $\mathrm{NO}_{2}$ columns are obtained from http://www.temis.nl/airpollution/no2.html. We use monthly mean data from the merged GOME/SCIAMACHY/GOME2 product over the 1996-2017 period $^{8}$. In this product, the Global Ozone Monitoring Experiment (GOME) and GOME-2 data are "corrected" relative to the SCanning Imaging Absorption spectroMeter for Atmospheric CHartographY (SCIAMACHY) data to produce a self-consistent dataset that covers the period April 1996-September 2017. We average annual mean data in the land area bounded by $40^{\circ}-60^{\circ} \mathrm{N}$ and $10^{\circ} \mathrm{W}-25^{\circ} \mathrm{E}$ and calculate data for each year as percent of levels in 1996, when the satellite record began, for comparison with trends in anthropogenic $\mathrm{NO}_{\mathrm{x}}$ emissions.

Temperature data and drought index. Monthly time series of $0.5^{\circ} \times 0.5^{\circ}$ gridded daily maximum temperature $\left(\mathrm{T}_{\max }\right)$ are obtained from the Climatic Research Unit TS v4.03 database ${ }^{83}$. Daily $\mathrm{T}_{\max }$ data are provided by the U.S. Climate Prediction Center from the website at https://www.esrl.noaa.gov/psd/. The Global Land-Based Datasets for Monitoring Climate Extremes (available at http://www.climdex.org/viewdownload.html) ${ }^{84}$ are used to examine trends in the frequency of warm days (Extended Data Fig.9). We define drought events using the Standardized Precipitation-Evapotranspiration Index (SPEI), a multiscalar drought index based on climatic data ${ }^{69}$. SPEI can be calculated over a variable integration time scale (e.g., SPEI03, 3month SPEI, integrates water status over the previous 3 months), with more negative values indicating more severe drought relative to long-term average conditions. We use SPEI03 $<-1$ and SPEI06 $<-1$ as the threshold for a drought event to calculate the percentage of land area in drought over western Europe $\left(40^{\circ} \mathrm{N}-55^{\circ} \mathrm{N}, 5^{\circ} \mathrm{W}-25^{\circ} \mathrm{E}\right)$.

Ozone flux measurements. The flux of ozone was measured by the eddy-covariance method over the Ulborg spruce forest in Denmark during July 1992 (dry) and June 1994 (wet) ${ }^{85}$, and over the Castelporziano Holm oak forest in central Italy during August 2003 (dry) and August 2004 (wet) 29. Note that climate in June 1994 was characterized as relatively wet conditions in Northern Europe (Fig.3d), although drought conditions set in quickly in July 1994 associated with a recordbreaking heatwave (Extended Data Fig.5). The measurements in Ulborg were carried out from a $36 \mathrm{~m}$ tall mast placed in a Norway spruce plantation with trees of a height of approximately $12 \mathrm{~m}$ $(\mathrm{LAI}=8)$. The fluxes were corrected for errors due to changes in the atmospheric density caused by heat and water vapor flux ${ }^{86}$. Values were discarded when no clear peak in flux versus lag time could be identified. This was usually associated with periods with low wind speed $(<1 \mathrm{~m} / \mathrm{s})$ during the night.

For the Italian site, the instrumentation was mounted on top of an 18-m fire watching tower located in the Holm oak forest with an average tree height between 12 and $13 \mathrm{~m}$ (LAI = 4.1 - 4.5). Only original measurement data without any gap-filling are used. In the measured ozone flux time series some spikes were present, mostly in correspondence with the changes of the coumarin target which required some hours to stabilise, and occasionally at night where some great positive (upward) fluxes occurred. We remove these outliers, adopting the mean - 3 standard deviations of the halfhourly time series of the total ozone fluxes in the central hours of the day (10 am - $4 \mathrm{pm})$ as the upper limit, and the mean +3 standard deviations of the half-hourly time series during the night $(0 \mathrm{am}-6 \mathrm{am})$ as the lower limit. The main consequence of this procedure, similar to the one proposed by ref.87, is the removal of abnormally negative fluxes during the day and unrealistic 
positive fluxes during the night. Repeating this methodology for each month, any half-hourly values falling outside the limits are rejected, leading to the removal of $0.76 \%$ of the data.

For both sites, the dry deposition velocity $\left(\mathrm{V}_{\mathrm{d}, \mathrm{O} 3}\right)$, i.e., a mass-transfer coefficient that relates the bulk-air concentration to the flux of ozone to a surface, is calculated following $\mathrm{V}_{\mathrm{d}, \mathrm{O} 3}=-\mathrm{F}_{\mathrm{O} 3} / \mathrm{C}_{\mathrm{O} 3}$, where $\mathrm{F}_{\mathrm{O} 3}$ is the flux of ozone and $\mathrm{C}_{\mathrm{O} 3}$ is the concentration of ozone in the air.

Land model experiments and ozone deposition algorithms. Dry deposition velocities $\left(\mathrm{V}_{\mathrm{d}}\right)$ for ozone and other related tracers are calculated from the GFDL LM4.0 dynamic vegetation land model $^{88-91}$ with an interactive dry deposition scheme ${ }^{40,46}$ forced with observation-based meteorological fields ${ }^{70}$, historical $\mathrm{CO}_{2}$, and historical land use ${ }^{92}$ over the period 1948-2015. The ozone deposition algorithms, model configurations and evaluations are described in detail by Lin et al. ${ }^{40}$ and are briefly summarized here. Ozone deposition velocity is parameterized following an electrical circuit analogy ${ }^{46}$ :

$$
v_{d}=\left(R_{a}+\frac{1}{\frac{1}{R_{a c, g}+R_{b, g}+R_{g}}+\frac{1}{R_{a c, v}+\frac{1}{\left(R_{b, s}+R_{s t e m}\right)^{-1}+\left(R_{b, v}+\left(R_{c u t}^{-1}+\left(R_{m}+R_{s t o m}\right)^{-1}\right)^{-1}\right)^{-1}}}}\right)^{-1}
$$

Where $R_{a}$ is the aerodynamic resistance to the exchange of tracers between the canopy and the atmosphere; $R_{a c, g}$ and $R_{a c, v}$ are the in-canopy aerodynamic resistance to the ground and vegetation, respectively; $R_{b, g}, R_{b, s}$, and $R_{b, v}$ are the laminar resistance to the ground, stem, and leaf surfaces, respectively; $R_{\text {stem }}$ is the stem resistance, and $R_{m}$ is the mesophyll resistance, parameterized as in ref. 46. Canopy cuticle resistances $\left(R_{c u t}\right)$ are considered separately for dry and wet conditions, with wet leaves facilitating cuticular deposition ${ }^{46}$. For temperate deciduous and tropical forests, the reference resistance is $400 \mathrm{~s} \mathrm{~m}^{-1}$ to wet-cuticular deposition and $6000 \mathrm{~s} \mathrm{~m}^{-1}$ to dry-cuticular deposition; and for grasses, pastures, crops and evergreen forests, the reference values are $200 \mathrm{~s} \mathrm{~m}^{-1}$ for wet leaves and 4000 for dry leaves ${ }^{93}$. The model also accounts for the influence of surface wetness on the ground resistance $\left(R_{g}\right)$, with wet soil inhibiting ozone deposition to the ground ${ }^{94}$. The reference ground resistance is $200 \mathrm{~s} \mathrm{~m}^{-1}$ for dry vegetated surfaces and $500 \mathrm{~s} \mathrm{~m}^{-1}$ for wet soil ${ }^{93}$.

While our model accounts for the effects of surface wetness on cuticular and soil uptakes, these non-stomatal processes do not substantially influence simulated interannual variability in total $\mathrm{V}_{\mathrm{d}, \mathrm{O} 3}$. Instead, year-to-year variability in total $\mathrm{V}_{\mathrm{d}, 03}$ is primarily controlled by stomatal pathways, which account for $\sim 75 \%$ of the total daytime $\mathrm{V}_{\mathrm{d}, \mathrm{O} 3}$ for natural or secondary vegetation, $40 \%$ for croplands, and $35 \%$ for pastures in the $\operatorname{model}^{40}$. Calculation of stomatal resistance $R_{\text {stom }}$ follows:

$R_{\text {stom }}=\frac{\sqrt{\frac{M\left(O_{3}\right)}{M\left(H_{2} O\right)}}}{g_{s}\left(H_{2} O\right)}$
$g_{s}\left(H_{2} O\right)=\max \left(\frac{m \bar{A}_{n}}{\left(C_{i}-\Gamma_{*}\right)\left(1+D_{s} / D_{0}\right)}, g_{s, \text { min }}\right) \cdot \psi_{i} \cdot \psi_{w} \cdot L A I$

Where $\mathrm{M}$ is the molecular weight; $g_{s}\left(\mathrm{H}_{2} \mathrm{O}\right)\left(\mathrm{mol} \mathrm{H}_{2} \mathrm{O} \mathrm{m} \mathrm{m}^{-2} \mathrm{~s}^{-1}\right)$ is the stomatal conductance for water; $\bar{A}_{n}$ is the net photosynthesis rate $\left(\mathrm{mol} \mathrm{CO} \mathrm{m}^{-2} \mathrm{~s}^{-1}\right)$ for a well-watered plant averaged over 
the entire canopy depth ${ }^{95} ; m$ is an empirical coefficient; $D_{s}$ is canopy air water vapor deficit $(\mathrm{kg}$ $\mathrm{H}_{2} \mathrm{O} \mathrm{kg}^{-1}$ air, $D_{0}$ is a reference value); $C_{i}$ is intercellular concentration of $\mathrm{CO}_{2}\left(\mathrm{~mol} \mathrm{CO}_{2} \mathrm{~mol}^{-1}\right.$ air); $\Gamma_{*}$ is the $\mathrm{CO}_{2}$ compensation point; $g_{s, \min }=0.01 \mathrm{~mol} \mathrm{H}_{2} \mathrm{O} \mathrm{m}^{-2} \mathrm{~s}^{-1}$ is the minimum stomatal conductance for water vapor allowed in the model, and LAI is leaf area index. $\psi_{i}$ is the limitation due to canopy wetness. $\psi_{w}$ is the limitation imposed by soil water stress, determined by the ratio of water supply from soil-root interface to the transpiration demand at non-water limited stomatal conductance ${ }^{40,95,96}$. The model does not account for in-canopy chemistry and ozone damage to vegetation.

Compared to the widely-used Wesely (1989) scheme, in which the expression for stomatal resistance depends only on solar radiation and temperature ${ }^{31-35}$, or the Javis's empirical function ${ }^{48}$ used in some air quality models ${ }^{36-39}$, the most novel feature of the GFDL dry deposition scheme is the photosynthesis-based parameterization of stomatal deposition, accounting for the influence from soil water stress, vapor pressure deficits, and atmospheric $\mathrm{CO}_{2}$ concentrations. Incorporated into a dynamic vegetation model, these new features allow the scheme to represent successfully the observed reductions in ozone removal by water-stressed vegetation during large-scale North American (e.g., 2011-2012) and European droughts (e.g., 2003) as well as during the dry season in Mediterranean Europe, South Asia, the Amazon, and the U.S. Pacific Northwest ${ }^{40}$.

Modelled land surface hydrology (e.g., soil moisture) is sensitive to the forcing dataset that drives $\mathrm{it}^{53}$. The impact of precipitation uncertainties on $\mathrm{V}_{\mathrm{d}, \mathrm{O}}$ is found to be of at least the same magnitude as interannual variability ${ }^{40}$. Therefore, to mimic the influence from observed climate as much as possible, we use $\mathrm{V}_{\mathrm{d}, \mathrm{O} 3}$ from LM4.0 forced with observed atmospheric forcings (including precipitation) as opposed to calculating $\mathrm{V}_{\mathrm{d}, \mathrm{O} 3}$ online in the atmospheric model AM4.

Land use. The model represents small-scale heterogeneity of the land surface and vegetation in each grid cell using a mosaic approach, as a combination of sub-grid tiles in four land use categories: croplands, pastures, lands undisturbed by human activity (i.e., "primary" or "natural"), and lands harvested at least once (i.e., "secondary"), including managed forests and abandoned croplands and pastures ${ }^{88}$. The model does not include urban land use. Transitions among the four land-use types are prescribed from the historical reconstruction used in the Coupled Model Intercomparison Project Phase 5 (CMIP5) ${ }^{92}$. Simulated LAI for forests agree with the field-based observations within $\pm 10 \%\left(\right.$ ref. ${ }^{40}$ ). Secondary lands grew substantially over western Europe during 1960-2015, resulting from natural wood harvesting and abandoned agricultural lands (Extended Data Fig.6 and Fig.7a). Conversion of croplands and pastures to secondary forests may lead to an increase in LAI and a stronger response to drought stress. Conversion of natural forests to secondary vegetation leads to a slight decrease in LAI. The average LAI shows only marginal increases $\left(<0.5 \mathrm{~m}^{2} / \mathrm{m}^{2}\right)$ during 1960-2015. Overall, we do not find a substantial impact of these land use changes on ozone deposition velocity. Instead, reduced stomatal conductance by natural and secondary forests under drought stress plays a dominant role in shaping year-to-year variability and long-term trends in ozone deposition rates (Extended Data Fig.7c-7d).

$\mathrm{CO}_{2}$ fertilization. Climate models simulate reductions in stomatal conductance by vegetation in the late $21^{\text {st }}$ century due to a three-fold increase in atmospheric $\mathrm{CO}_{2}$ concentrations ${ }^{75}$, as supported by recent observational evidence ${ }^{97}$. We probe the influence of the $\mathrm{CO}_{2}$ fertilization with a sensitivity experiment with $\mathrm{CO}_{2}$ concentration set to the preindustrial level. Comparing simulated 
$\mathrm{V}_{\mathrm{d}, \mathrm{O} 3}$ from the sensitivity experiment with our base simulation with historical $\mathrm{CO}_{2}$, we do not find a substantial influence from the $\mathrm{CO}_{2}$ fertilization during our study period 1960-2015. Increases in $\mathrm{CO}_{2}$ concentrations during our study period are small compared to the increases in the late $21^{\text {st }}$ century.

Chemistry-climate model experiments. We conduct hindcast simulations (1960-2015) with the GFDL-AM4 chemistry-climate model at $\sim 100 \times 100 \mathrm{~km}^{2}$ horizontal resolution ${ }^{91}$ with AM3-like full chemistry nudged to NCEP reanalysis winds ${ }^{47,98,99}$. Three experiments are designed to isolate the response of ozone concentrations to changes in climate, dry deposition velocities, and anthropogenic emissions of ozone precursors. The IAVDEPV experiment applies interannually varying $\mathrm{V}_{\mathrm{d}, \mathrm{O} 3}$ from LM4.0, interannually varying wildfire emissions ${ }^{100}$, historical anthropogenic emissions used in the Coupled Model Intercomparison Project Phase 6 (CMIP6) ${ }^{7}$, and observed historical $\mathrm{CH}_{4}$ mixing ratios as lower boundary conditions for chemistry. Trends in anthropogenic emissions of CO and NMVOCs over Europe are similar to those for $\mathrm{NO}_{\mathrm{x}}$, increasing during 19601980, followed by a plateau in the 1980s and a rapid decline beyond 1990 (Extended Data Fig.2). The FIXDEPV simulation uses the same emissions as in IAVDEPV, but with $\mathrm{V}_{\mathrm{d}, \mathrm{O} 3}$ held constant at the 1960 level from LM4.0. With $\mathrm{V}_{\mathrm{d}, \mathrm{O} 3}$ varying as in IAVDEPV but using 1980 anthropogenic emissions from CMIP6, the IAVDEPV_FIXEM experiment isolates the role of climate change under constant high-emission conditions. Since anthropogenic emissions in Europe are largest in the 1980s, the IAVDEPV_FIXEM experiment enables us to assess the ozone climate penalty under polluted conditions.

In all simulations, biogenic isoprene emissions respond to fluctuations in solar radiation and temperature, following the Model of Emissions of Gases and Aerosols from Nature (MEGAN), using 17 plant functional types and corresponding leaf area indices based on satellite data ${ }^{45,63}$. Note that these vegetation types and leaf area indices are independent of those within the LM4.0 dynamic vegetation model. Simulated biogenic isoprene emissions over Europe increase by approximately $1 \%$ per year since 1980 , with greater emissions in hot summers, consistent with increases in surface air temperature (Extended Data Fig.2d). The models apply climatological emissions of other biogenic VOCs and of $\mathrm{NO}_{\mathrm{x}}$ from soils ${ }^{101}$, which may contribute to an underestimate of the ozone climate penalty factor (Fig.6). Uncertainties in the trends of the anthropogenic $\mathrm{NO}_{x} / \mathrm{CO}$ or $\mathrm{NO}_{x} / \mathrm{VOCs}$ emissions ratio in global emission inventories ${ }^{102}$ may also contribute to excessive ozone reductions from emission controls simulated in chemistry models (Extended Data Fig.3) and the resulting underestimate of the ozone climate penalty factor in simulations where emissions are varying (e.g., FIXDEPV and IAVDEPV).

Impacts of rising Asian emissions and global methane. We analyze a suite of chemistry-climate model hindcast simulations designed to isolate the contributions of rising Asian anthropogenic emissions, global methane abundance, and wildfire emissions to decadal mean ozone trends from the 1980s (1979-1989) to the 2000s (2001-2010) as measured at the surface site of Hohenpeissenberg and the alpine site of Zugspitze (Extended Data Fig.10) . For the 2000s, we use the 2001-2010 period (as opposed to the 2001-2015 period) for two reasons: (1) ozone observations at the Zugspitze ended in 2011; and (2) $\mathrm{NO}_{\mathrm{x}}$ emissions in China decreased after 2011 8,103 . These simulations are described in detail in ref. 21 and were previously used to interpret the causes of tropospheric ozone trends measured at Mauna Loa Observatory in Hawaii ${ }^{47}$, interannual variability of springtime surface ozone over the western U.S. ${ }^{20,99}$, as well as the trends and extreme events of summertime ozone in the eastern U.S. over recent decades ${ }^{21}$. The purple bars shown in 
Extended Data Fig.10 represent the differences between an experiment with global anthropogenic emissions held constant in time and an experiment with only Asian anthropogenic emissions varying in time over 1979-2010. A similar approach is used to calculate the contributions from changes in global methane and wildfire emissions; as such the influence from meteorological variability is removed. Our BASE (IAVDEPV) model captures the observed changes in decadal mean ozone over Europe in the 2000s relative to the 1980s and the 1990s, lending confidence in model ability to relate the observed ozone changes to specific processes. The impact of rising Asian emissions and global methane concentrations on summertime surface ozone over Europe is less than $1 \mathrm{ppb}$. The climate-driven increases ( $\sim 5 \mathrm{ppb}$; green bars in Extended Data Fig.10) dominate the changes of summer ozone in surface air over Europe, offsetting the benefits of regional emission controls.

Data availability. Ozone flux measurements, the ozone climate penalty factors derived from observations, and model simulations generated in this study are archived at a public data repository at NOAA GFDL (ftp://data1.gfdl.noaa.gov/users/Meiyun.Lin/Nature2020/). Ozone deposition velocities from LM4.0 are archived at ftp://data1.gfdl.noaa.gov/users/Meiyun.Lin/GBC2019/GFDL-LM4/.

Code availability. The computer code for the standard versions of GFDL's atmospheric and land models is publicly available at https://www.gfdl.noaa.gov/atmospheric-model/. Other codes used in this study are available from the corresponding author upon reasonable request.

\section{References:}

82 Schultz, M. G. et al. Tropospheric Ozone Assessment Report: Database and metrics data of global surface ozone observations. Elementa-Sci Anthrop 5, doi:10.1525/elementa.244 (2017).

83 Harris, I., Jones, P. D., Osborn, T. J. \& Lister, D. H. Updated high-resolution grids of monthly climatic observations - the CRU TS3.10 Dataset. Int. J. Clim. 34, 623-642, doi:10.1002/joc.3711 (2014).

84 Donat, M. et al. Global Land-Based Datasets for Monitoring Climatic Extremes. Bull. Amer. Meteor. Soc. 94, 997-1006, doi:10.1175/Bams-D-12-00109.1 (2013).

85 Pilegaard, K., Jensen, N. O. \& Hummelshoj, P. Seasonal and diurnal variation in the deposition velocity of ozone over a spruce forest in Denmark. Water Air Soil Poll 85, 2223-2228, doi:10.1007/Bf01186164 (1995).

86 Webb, E. K., Pearman, G. I. \& Leuning, R. Correction of flux measurements for density effects due to heat and water vapour transfer. Quarterly Journal of the Royal Meteorological Society 106, 85-100 (1980).

87 Vickers, D. \& Mahrt, L. Quality control and flux sampling problems for tower and aircraft data. J Atmos Ocean Tech 14, 512-526, doi:10.1175/15200426(1997)014<0512:QCAFSP>2.0.CO;2 (1997).

88 Shevliakova, E. et al. Carbon cycling under 300 years of land use change: Importance of the secondary vegetation sink. Global Biogeochem. Cycles 23, doi:10.1029/2007gb003176 (2009).

89 Malyshev, S., Shevliakova, E., Stouffer, R. J. \& Pacala, S. W. Contrasting Local versus Regional Effects of Land-Use-Change-Induced Heterogeneity on Historical Climate: Analysis with the GFDL Earth System Model. J. Clim. 28, 5448-5469, doi:10.1175/Jcli-D14-00586.1 (2015). 
90 Zhao, M. et al. The GFDL Global Atmosphere and Land Model AM4.0/LM4.0:2. Model Description, Sensitivity Studies, and Tuning Strategies. Journal of Advances in Modeling Earth Systems 10, 735-769, doi:10.1002/2017ms001209 (2018).

91 Zhao, M. et al. The GFDL Global Atmosphere and Land Model AM4.0/LM4.0:1. Simulation Characteristics With Prescribed SSTs. Journal of Advances in Modeling Earth Systems 10, 691-734, doi:10.1002/2017ms001208 (2018).

92 Hurtt, G. C. et al. Harmonization of land-use scenarios for the period 1500-2100: 600 years of global gridded annual land-use transitions, wood harvest, and resulting secondary lands. Climatic Change 109, 117-161, doi:10.1007/s10584-011-0153-2 (2011).

93 Zhang, L. M., Brook, J. R. \& Vet, R. A revised parameterization for gaseous dry deposition in air-quality models. Atmos. Chem. Phys. 3, 2067-2082, doi:10.5194/acp-3-2067-2003 (2003).

94 Massman, W. J. Toward an ozone standard to protect vegetation based on effective dose: a review of deposition resistances and a possible metric. Atmos. Environ. 38, 2323-2337, doi:10.1016/j.atmosenv.2003.09.079 (2004).

95 Weng, E. S. et al. Scaling from individual trees to forests in an Earth system modeling framework using a mathematically tractable model of height-structured competition. Biogeosciences 12, 2655-2694, doi:10.5194/bg-12-2655-2015 (2015).

96 Milly, P. C. D. et al. An Enhanced Model of Land Water and Energy for Global Hydrologic and Earth-System Studies. J Hydrometeorol 15, 1739-1761, doi:10.1175/JhmD-13-0162.1 (2014).

97 Lammertsma, E. I. et al. Global CO2 rise leads to reduced maximum stomatal conductance in Florida vegetation. Proc. Natl. Acad. Sci. U.S.A. 108, 4035-4040, doi:10.1073/pnas.1100371108 (2011).

98 Lin, M. et al. Transport of Asian ozone pollution into surface air over the western United States in spring. J. Geophys. Res. 117, doi:10.1029/2011jd016961 (2012).

99 Lin, M. et al. Climate variability modulates western U.S. ozone air quality in spring via deep stratospheric intrusions. Nat. Commun. 6, doi:10.1038/ncomms8105 (2015).

100 van der Werf, G. R. et al. Global fire emissions estimates during 1997-2016. Earth Syst. Sci. Data, 9, 697-720, doi:10.5194/essd-9-697-2017 (2017).

101 Horowitz, L. W. Past, present, and future concentrations of tropospheric ozone and aerosols: Methodology, ozone evaluation, and sensitivity to aerosol wet removal. $J$. Geophys. Res. 111, doi:10.1029/2005jd006937 (2006).

102 Hassler, B. et al. Analysis of long-term observations of NOx and CO in megacities and application to constraining emissions inventories. Geophys. Res. Lett. 43, 9920-9930, doi:10.1002/2016gl069894 (2016).

103 Duncan, B. N. et al. A space-based, high-resolution view of notable changes in urban NOx pollution around the world (2005-2014). J. Geophys. Res. 121, 976-996, doi:10.1002/2015jd024121 (2016).

Acknowledgments. This report was prepared by Meiyun Lin under awards NA14OAR4320106 and NA18OAR4320123 from the National Oceanic and Atmospheric Administration (NOAA), U.S. Department of Commerce. The statements, findings, conclusions, and recommendations are those of the authors and do not necessarily reflect the views of NOAA. We thank GFDL internal reviewers, Keith Dixon and John Krasting, for constructive comments, which have helped to strengthen the article. 
Author contributions. ML conceived this study, performed the model experiments and analysis, and wrote the article. ML, LWH, and ES designed the model experiments. YX performed the ozone-temperature regression analysis under the supervision of ML. FP, ML, SM, and ES developed the dry deposition scheme. AF, GG, and KP provided ozone flux measurements. DK provided surface ozone measurements at Hohenpeissenberg. All authors contributed to discussions and edited the manuscript.

Competing interests. The authors declare no competing interests.

Correspondence and requests for materials should be addressed to M. Lin (Meiyun.Lin@noaa.gov).

\section{Figure Captions [675 words]:}

Fig.1 | Correlations between ozone air quality and temperature in Europe. (a) Time series of June-August mean maximum daily 8-hour average (MDA8) ozone anomalies (relative to 1980-2000) measured at the Hohenpeissenberg surface site and the alpine sites of Zugspitze, Jungfraujoch and Sonnblick, along with observed anomalies in summer mean daily maximum temperature ( $\mathrm{T}_{\max }$; right axis). The ozone-temperature regression slopes $\left(\mathrm{m}_{\mathrm{O} 3-\mathrm{T}}\right)$ and correlations $\left(\mathrm{r}^{2}\right)$ are shown separately for the periods before and after the year 2000 (in parenthesis). (b) Trends in anthropogenic $\mathrm{NO}_{\mathrm{x}}$ emissions (lines) and satellite-derived tropospheric $\mathrm{NO}_{2}$ columns (dots) over Europe $\left(40^{\circ}-60^{\circ} \mathrm{N}, 10^{\circ} \mathrm{W}-25^{\circ} \mathrm{E}\right)$, expressed as percent of levels in 1996 when satellite data began. The inset map shows the annual $26^{\text {th }}$ MDA8 ozone measured at EMEP sites averaged over 2000-2015, with sites marked as dots in the last two color categories implying an exceedance of the EU limit. Triangles denote the sites shown in (a).

Fig.2 | Changes in European ozone air quality. (a) Probability distributions of MDA8 ozone concentrations in June-August measured at Hohenpeissenberg for 1979-1989 versus 2001-2015. (b) Probability distributions of MDA8 ozone in July at EMEP sites for 1990-2000 versus 20012015 and during the extreme heatwaves of 1994 and 2006. (c) Same as (b) but for August and during the 2003 heatwave. The median value $(\mu)$ and the percentage of site-days with MDA8 ozone $\geq 60 \mathrm{ppb}(\mathrm{D} 60)$ are shown.

Fig.3 | Reduced ozone removal by forests under drought stress. (a) Drought conditions in August 2003 versus August 2004 as expressed in SPEI integrated over the preceding 6 months. (b-c) Mean diurnal cycle of ozone deposition velocities $\left(\mathrm{V}_{\mathrm{d}, \mathrm{O} 3}\right)$ over a Holm Oak forest in Italy (red circle on map) for August 2003 versus 2004 from observations and GFDL-LM4 simulations. (d-f) Same as (a-c) but for July 1992 versus June 1994 over a spruce forest in Denmark.

Fig.4 | Declining ozone removal by water-stressed vegetation in a warming climate. (a-b) Time series of modeled June-August mean daytime (9am-3pm) $\mathrm{V}_{\mathrm{d}, \mathrm{O} 3}$ (green lines) averaged over natural forests and secondary vegetation (i.e., lands harvested at least once, including managed forests and abandoned croplands and pastures) in western Europe (box on map), along with the observed mean $\mathrm{T}_{\max }$ (magenta bars) and the percentage area in drought based on March-August SPEI $<-1$ (brown bars). The orange bars denote the summers with the percentage area in drought greater than $30 \%$ based on June-August SPEI $<-1$. (c-e) Daytime $\mathrm{V}_{\mathrm{d}, \mathrm{O} 3}$ anomalies (relative to 
1980-2000) for August 2003, July 1994, and July 2006, with dots indicating areas in drought (SPEI06 <-1 for 2003 and SPEI02 <-1 for 1994 and 2006).

Fig.5 | Reduced uptake by plants worsens ozone air pollution extremes. (a) Time series of July mean MDA8 ozone anomalies relative to 1980-2000 from: Hohenpeissenberg (black) and alpine (gray) observations, and model simulations sampled in the surface level, with $\mathrm{V}_{\mathrm{d}, \mathrm{O} 3}$ fixed at 1960 levels (FIXDEPV), with $\mathrm{V}_{\mathrm{d}, \mathrm{O} 3}$ varying with climate and vegetation state (IAVDEPV), and with time-varying $\mathrm{V}_{\mathrm{d}, \mathrm{O} 3}$ but fixed-1980 anthropogenic emissions (IAVDEPV_FIXEM). (b) Same as (a) but for August. (c) Distributions of observed and simulated MDA8 ozone at EMEP sites in western Europe during July 1994, July 10 - August 15 of 2003, and July 2006. The 95th percentile (q95), standard deviation $(\sigma)$, and the percentage of site-days with MDA8 ozone $\geq 80$ ppb (D80) are shown.

Fig.6 | Ecosystem-atmosphere interactions exacerbate climate penalty on ozone extremes. (Top) Maps of median MDA8 ozone sensitivities to daily maximum temperature during July and August from observations $\left(0.5^{\circ} \times 0.5^{\circ} ; 2001-2018\right)$ and model simulations $\left(1^{\circ} \times 1^{\circ} ; 2001-2014\right)$ with constant $\mathrm{V}_{\mathrm{d}, \mathrm{O} 3}$ (FIXDEPV), with $\mathrm{V}_{\mathrm{d}, \mathrm{O} 3}$ coupled to vegetation and climate (IAVDEPV), and with varying $\mathrm{V}_{\mathrm{d}, \mathrm{O} 3}$ but fixed-1980 emissions (IAVDEPV_FIXEM). (Middle) Same as the top panels, but for the 95th percentile. (Bottom) Same as the middle panels, but for the 1990-2000 period. Stippling indicates the grid cells with the quantile regression coefficients $r<0.5$. Numbers on the top-left corner of each graph are the mean values ( \pm s.d.) and normalized mean biases (NMB) against observations in the grid cells with $r \geq 0.5$ in the land area bounded by $5^{\circ} \mathrm{W}-25^{\circ} \mathrm{E}$ and $40^{\circ}-55^{\circ} \mathrm{N}$.

\section{Extended Data Figures}

Extended Data Fig.1 | Ozone-temperature relationships. Scatter plots of observed June-August mean MDA8 ozone anomalies (relative to 1980-2000) at Hohenpeissenberg and Zugspitze and observed June-August mean $\mathrm{T}_{\max }$ anomalies averaged over $42^{\circ}-53^{\circ} \mathrm{N}$ and $0^{\circ}-15^{\circ} \mathrm{E}$, with linear regression fits using the Ordinary Least Squares (OLS, blue) and Reduced Major Axis (RMA, red) methods, respectively. The OLS regression slopes are reported in Fig. 1 in the main article.

Extended Data Fig.2 | Trends in ozone precursor emissions. (a-b) Trends in anthropogenic emissions of carbon monoxide and non-methane volatile organic compounds (NMVOCs) in Europe (40-60N; 10W-25E) from the CMIP6 historical dataset used by the model. (c) Observed trends in global average methane mixing ratios used by the model. (d) Model estimated trends in biogenic isoprene emissions over Europe $\left(40^{\circ}-60^{\circ} \mathrm{N} ; 10^{\circ} \mathrm{W}-25^{\circ} \mathrm{E}\right)$.

Extended Data Fig.3 | Surface ozone trends. Maps of the 1990-2015 trends in daily MDA8 ozone for the 95th and 50th percentiles in July and August from observations (top) and IAVDEPV simulations (bottom). Results are shown for EMEP sites with at least 20 years of data, with larger circles indicating sites with significant ozone trends $(p<0.05)$. The percentage of sites with significant trends are reported at the top-left corner of each graph. 
Extended Data Fig.4 | Ozone pollution during the 2015 and 2018 heatwaves. (Top) Maps of observed daily maximum temperature anomalies in June-August of 2015 and 2018 relative to the base period 1961-1990, with dots indicating area in drought (SPEI06 < -1). (Middle) The annual 4th highest MDA8 ozone concentrations from all available observations gridded at $0.5^{\circ}$ resolution, with values above $70 \mathrm{ppb}$ implying an exceedance of the health limit set by the U.S. Environmental Protection Agency. (Bottom) The annual 26th highest MDA8 ozone concentrations, with values above 60 ppb implying an exceedance of the health limit set by the European Union.

Extended Data Fig.5 | Evolution of drought events. The Standardized PrecipitationEvapotranspiration Index (SPEI) integrated over the preceding 6 months, 2 months, and 1 month for August 2003, July 1994 and July 2006.

Extended Data Fig.6 | Land use. (a) Fraction of the four land use categories in each grid cell averaged over 2000-2015: Natural forests (lands undisturbed by human activities), secondary vegetation (lands harvested at least once, including managed forests and abandoned cropland and pasture), croplands, and pastures. (b) Changes in 2000-2015 relative to the 1960s. The box denotes the area used for averaging in Extended Data Fig.7.

Extended Data Fig.7 | Declining ozone removal by vegetation due to stomatal closure under soil drying as opposed to land use changes. (a-b) Evolution of land use over western Europe $\left(5^{\circ} \mathrm{W}-25^{\circ} \mathrm{E}\right.$ and $\left.40^{\circ}-55^{\circ} \mathrm{N}\right)$ : total land areas and area-weighted leaf area indices for natural forests (dark green), secondary vegetation (green), croplands (orange), and pastures (blue). (c) Evolution of June-August mean daytime ozone deposition velocities for the four land use types (areaweighted). (d) Total (solid green lines) and stomatal (dashed green lines) ozone deposition velocities averaged over natural and secondary vegetation land areas. The vertical bars show the percentage of land areas in drought (SPEI06 <-1; right axis).

Extended Data Fig.8 | Climate-driven trends in surface ozone over Europe. Maps of the 1979-2014 and 1990-2014 trends in the 95th and 50th percentile MDA8 ozone concentrations for July and August, simulated by the IAVDEPV FIXEM experiment with anthropogenic emissions held constant at 1980 levels. Stippling denotes areas where the change is statistically significant at the $95 \%$ confidence level $(\mathrm{p}<0.05)$.

Extended Data Fig.9 | Observed trends in hot extremes over Europe. Maps of the 1979-2019 trends in the frequency of warm days (i.e., those above the 90th percentile for the base period 1961-1990) in July (a) and August (b), respectively, obtained from the Global Land-Based Datasets for Monitoring Climate Extremes (Methods). Stippling denotes areas where the change is statistically significant $(\mathrm{p}<0.05)$.

Extended Data Fig 10. | Drivers of decadal mean ozone trends in Europe. Changes in decadal mean ozone levels during spring (March-May) and summer (June-August) from 1979-1989 to 2001-2010 as inferred from surface observations at Hohenpeissenberg (985 m altitude, MDA8 values), from alpine observations at Zugspitze (2962 $\mathrm{m}$ altitude, 24-hour mean), and from 19902000 to 2001-2010 at 52 EMEP sites over $40^{\circ} \mathrm{N}-55^{\circ} \mathrm{N}$ with continuous observations (MDA8 values). For observations, both changes in decadal mean (gray bars) and median (circles) values are shown, with the error bars indicating the range of the mean change at the $95 \%$ confidence level. 
Model results are shown for the BASE and IAVDEPV FIXEM experiments and the contributions from changes in Asian anthropogenic emissions, global methane concentrations, and wildfire emissions. For comparisons with free tropospheric observations at the Zugspitze, model results are sampled at $700 \mathrm{hPa}$. 


\section{Observations (June-August)}

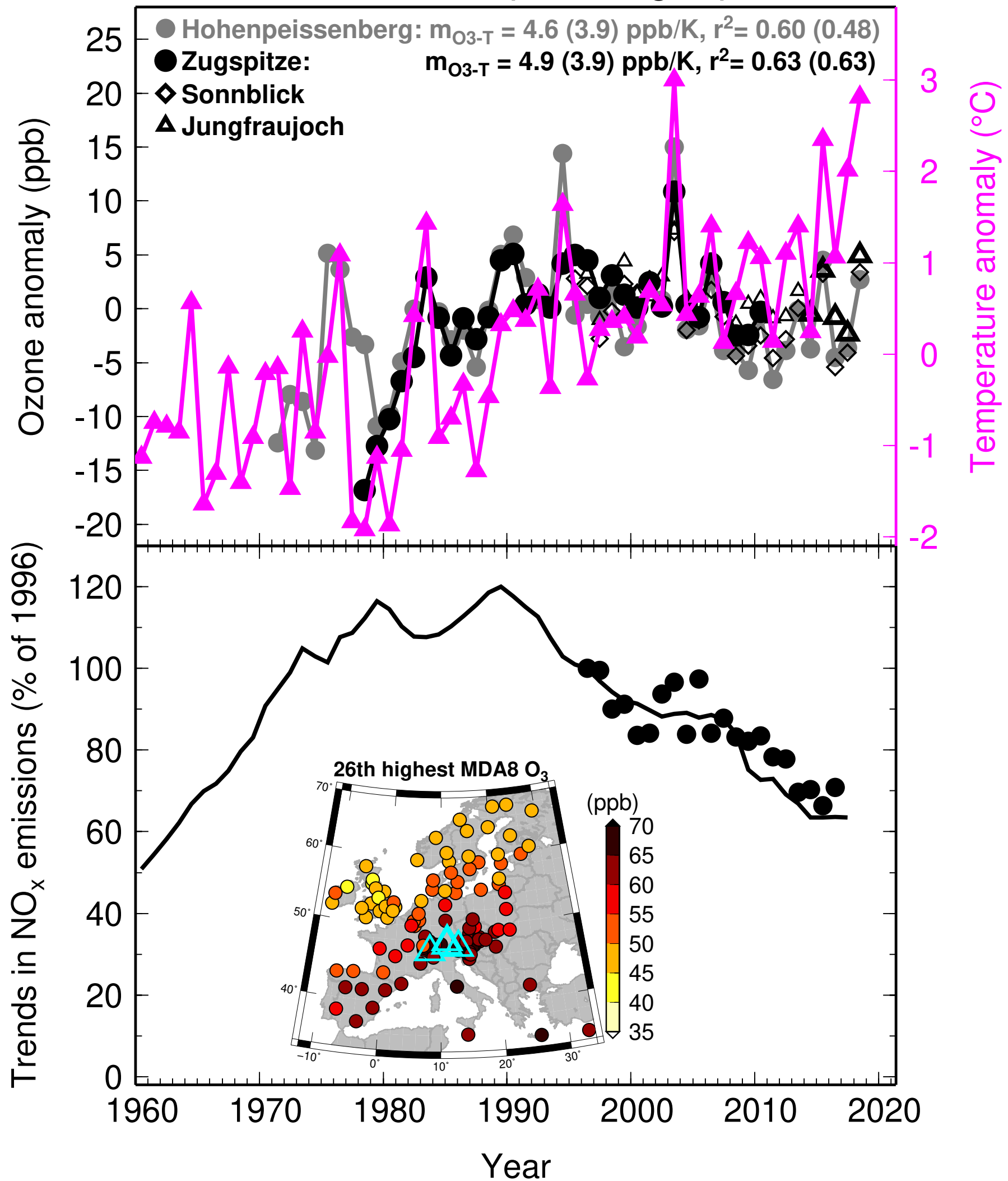

Figure 1. Correlations between ozone air quality and temperature in Europe. (a) Time series of June-August mean maximum daily 8-hour average (MDA8) ozone anomalies (relative to 1980-2000) measured at the Hohenpeissenberg surface site and the alpine sites of Zugspitze, Jungfraujoch and Sonnblick, along with observed anomalies in summer mean daily maximum temperature (right axis). The ozone-temperature regression slopes $\left(\mathrm{m}_{O 3-T}\right)$ and correlations $\left(\mathrm{r}^{2}\right)$ are shown separately for the periods before and after the year 2000 (in parenthesis). (b) Trends in anthropogenic $\mathrm{NO}_{x}$ emissions (lines) and tropospheric $\mathrm{NO}_{2}$ columns observed from space (dots) over Europe (40-60N,10W-25E), expressed as percent of levels in 1996 when satellite data began. The inset map shows the annual 26th highest MDA8 ozone measured at EMEP sites averaged over 2000-2015, with sites marked with dots in the last two colour categories implying an exceedance of the 60 -ppb target value. Triangles denote the sites shown in (a). 

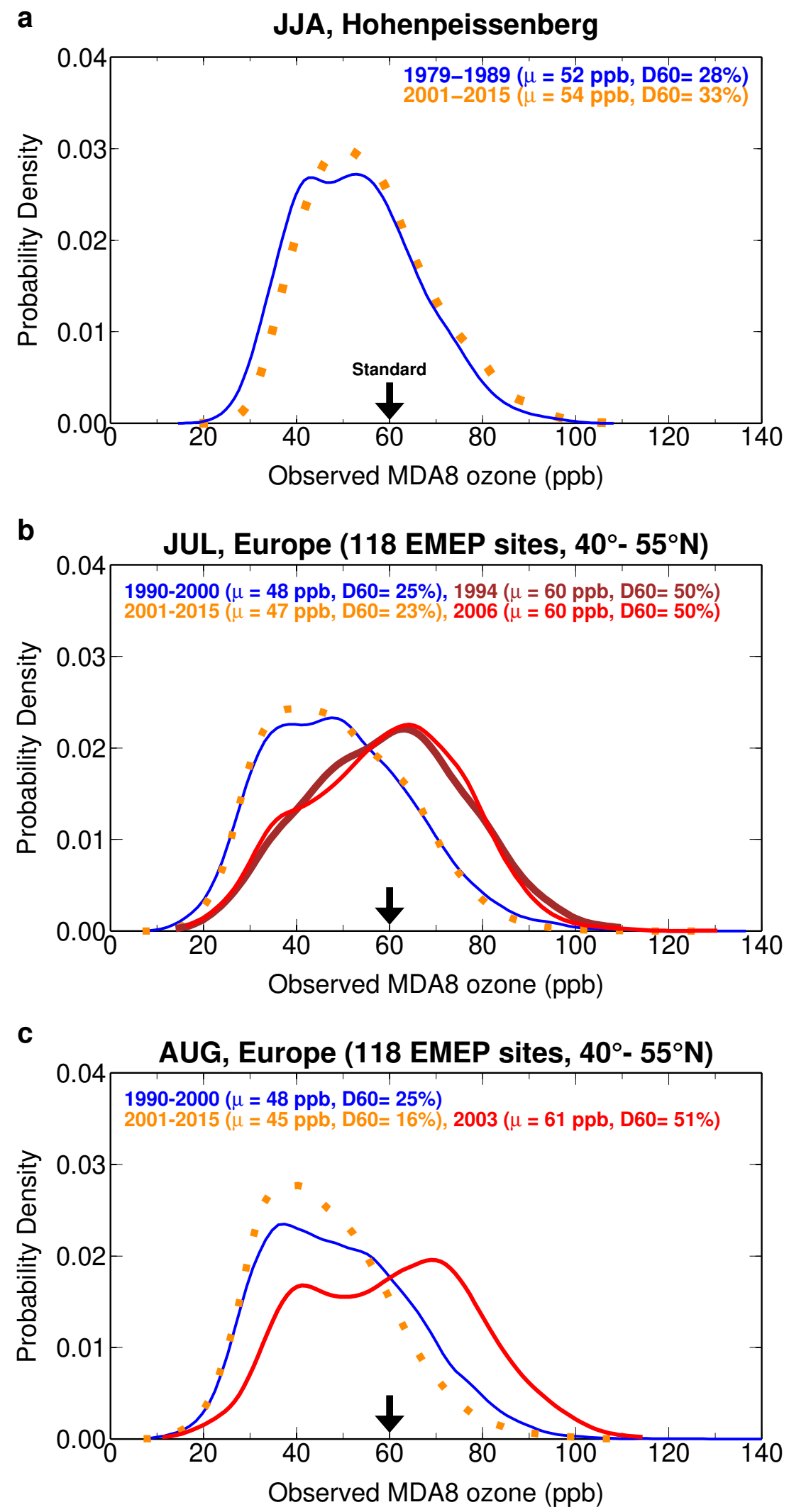

Figure 2. Changes in European ozone air quality. (a) Probability distributions of MDA8 ozone concentrations in June-August measured at Hohenpeissenberg for 1979-1989 (blue) versus 2001-2015 (dashed orange). (b) Probability distributions of MDA8 ozone in July at EMEP sites for 1990-2000 (blue) versus 2001-2015 (dashed orange) and during the extreme heatwaves of 1994 (brown) and 2006 (red). (c) Same as (b) but for August and during the heat wave of 2003 (red). The median value $(\mu)$ and the percentage of site-days with MDA8 ozone $\geq 60 \mathrm{ppb}(\mathrm{D} 60)$ are shown. 
a

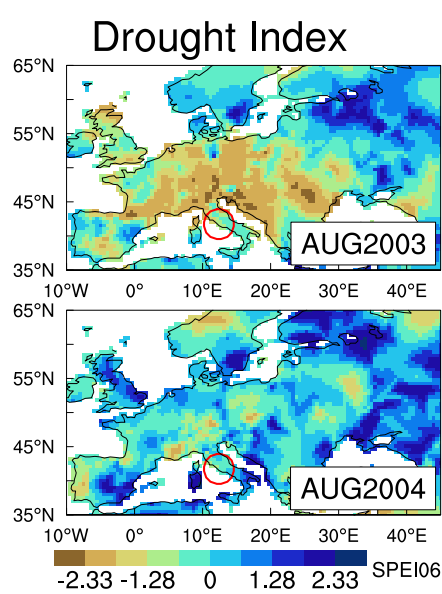

d

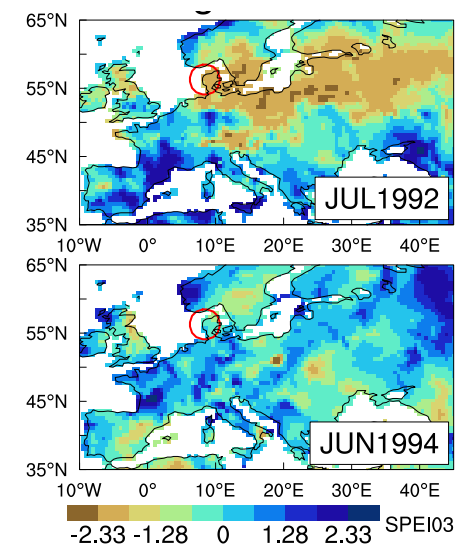

b

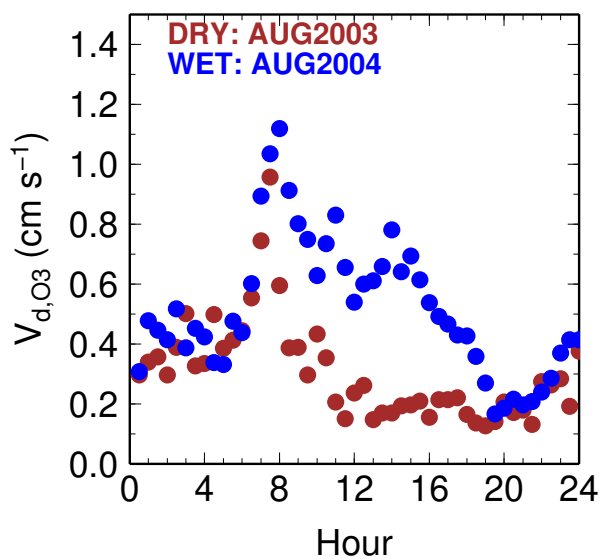

e

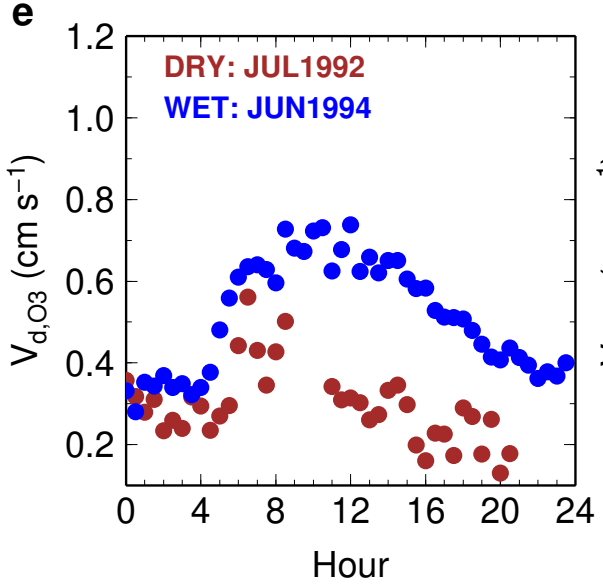

C
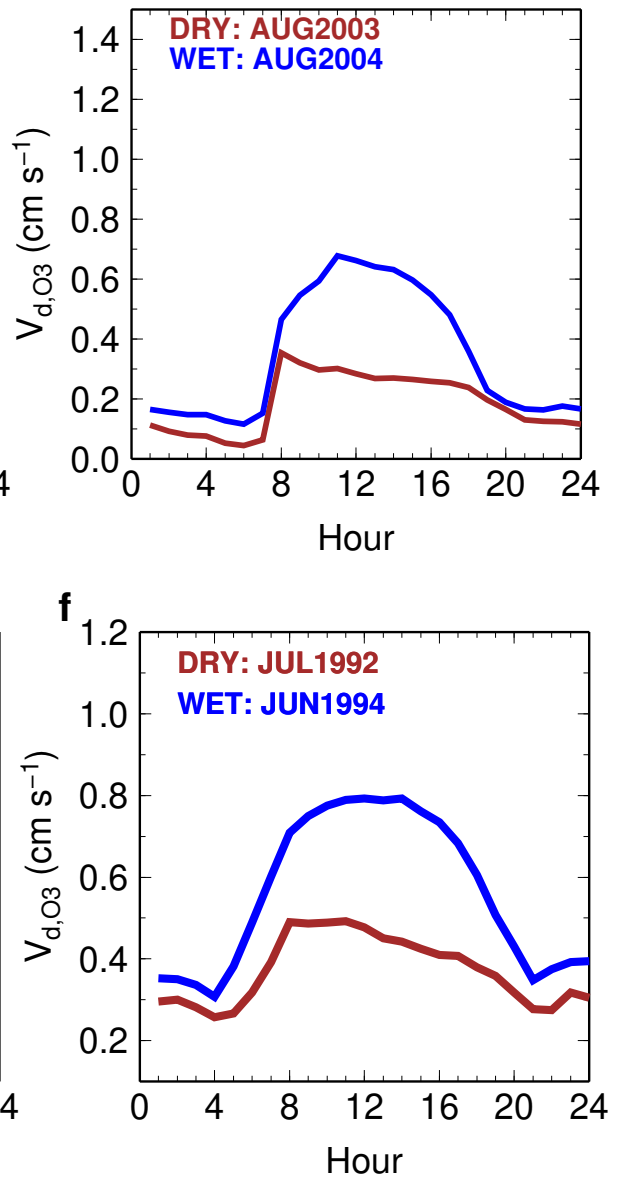

Figure 3. Reduced ozone removal by forests under drought stress. (a) Drought conditions in August 2003 versus 2004 as expressed in SPEI integrated over the preceding 6 months. (b-c) Mean diurnal cycle of ozone deposition velocities $\left(\mathrm{V}_{d, O 3}\right)$ over a Holm Oak forest in Italy (red circle on map) for August 2003 versus August 2004 from observations and GFDL-LM4 simulations. (d-f) Same as (a-c) but for July 1992 versus June 1994 over a spruce forest in Denmark. 

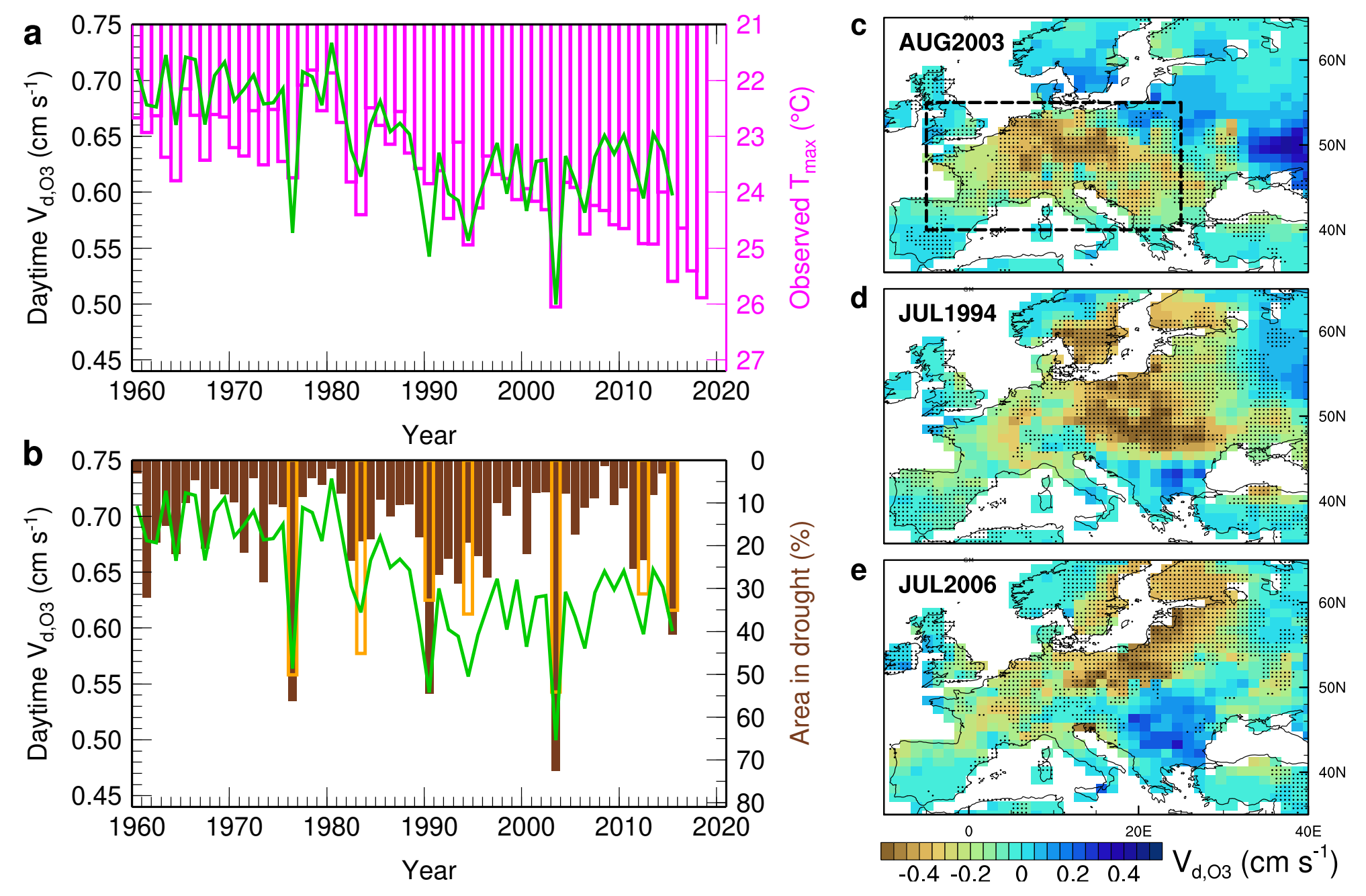

Figure 4. Declining ozone removal by water-stressed vegetation in a warming climate. (a-b) Time series of modeled June-August mean daytime (9am-3pm) $\mathrm{V}_{d, O 3}$ (green lines) averaged over natural forests and secondary vegetation (i.e., lands harvested at least once, including managed forests and abandoned croplands and pastures) in Western Europe (box on map), along with the observed mean $\mathrm{T}_{\max }$ (magenta bars) and the percentage area in drought based on March-August SPEI $<-1$ (brown bars). The orange bars denote the summers with the percentage area in drought greater than $30 \%$ based on June-August SPEI $<-1$. (c-e) Daytime $\mathrm{V}_{d, O 3}$ anomalies (relative to 1980-2000) for August 2003, July 1994, and July 2006, with dots indicating areas in drought (SPEI06 < -1 for 2003 and SPEI02 <-1 for 1994 and 2006). 

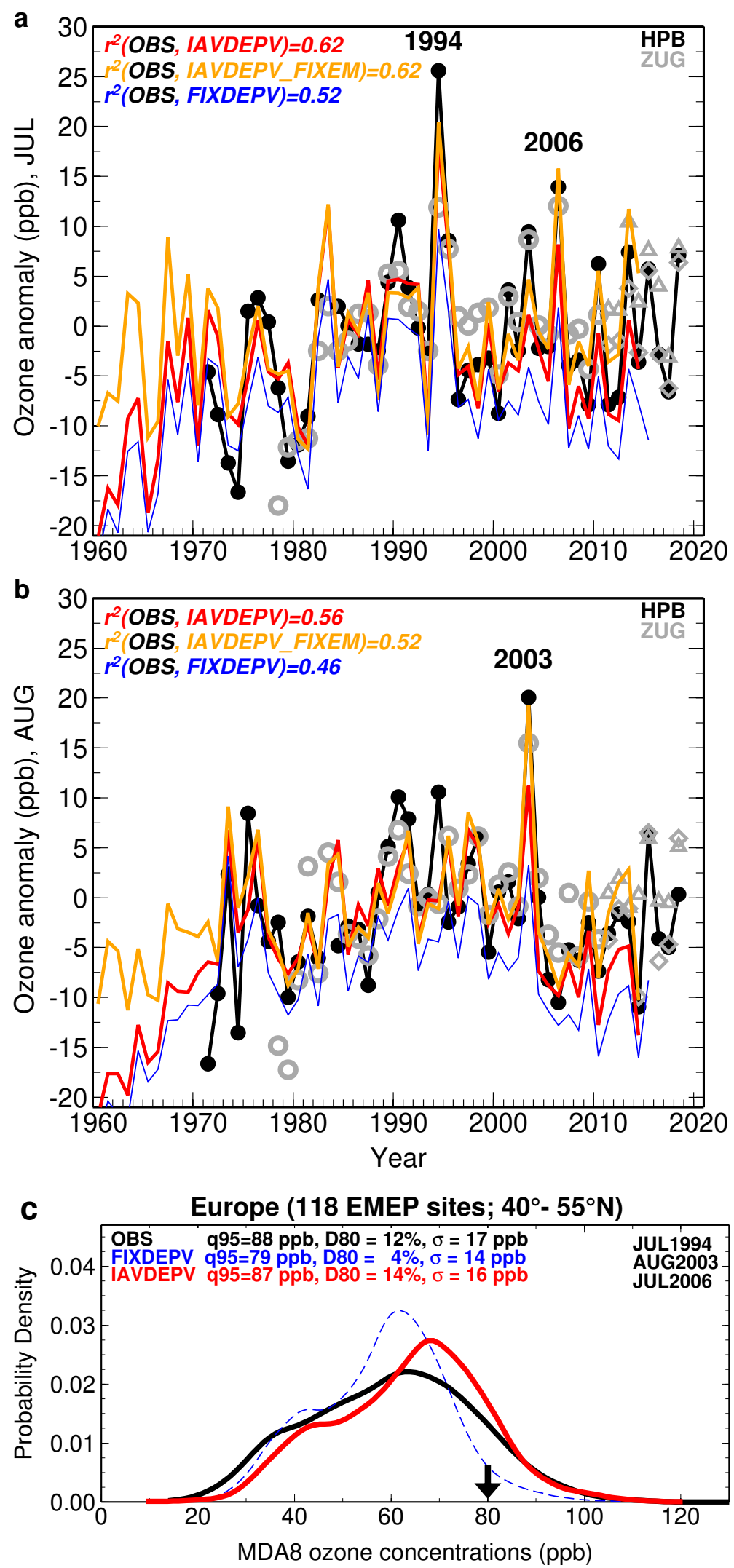

Figure 5. Reduced uptake by plants worsens ozone air pollution extremes. (a) Time series of July mean MDA8 ozone anomalies relative to 1980-2000 from: Hohenpeissenberg (black) and alpine (gray) observations and GFDL-AM4 simulations sampled in the surface level, with $\mathrm{V}_{d, O 3}$ fixed at 1960 levels (FIXDEPV), with $\mathrm{V}_{d, O 3}$ varying with climate and vegetation state (IAVDEPV), and with time-varying $\mathrm{V}_{d, O 3}$ but fixed-1980 anthropogenic emissions (IAVDEPV_FIXEM). (b) Same as (a) but for August. (c) Probability distributions of observed and simulated MDA8 ozone at EMEP sites over western Europe during July 1994, August 2003, and July 2006. The 95th percentile (q95) and standard deviation $(\sigma)$ are shown, as well as the percentage of site-days with MDA8 ozone $\geq 80 \mathrm{ppb}$ (D80). 
(a) Observations

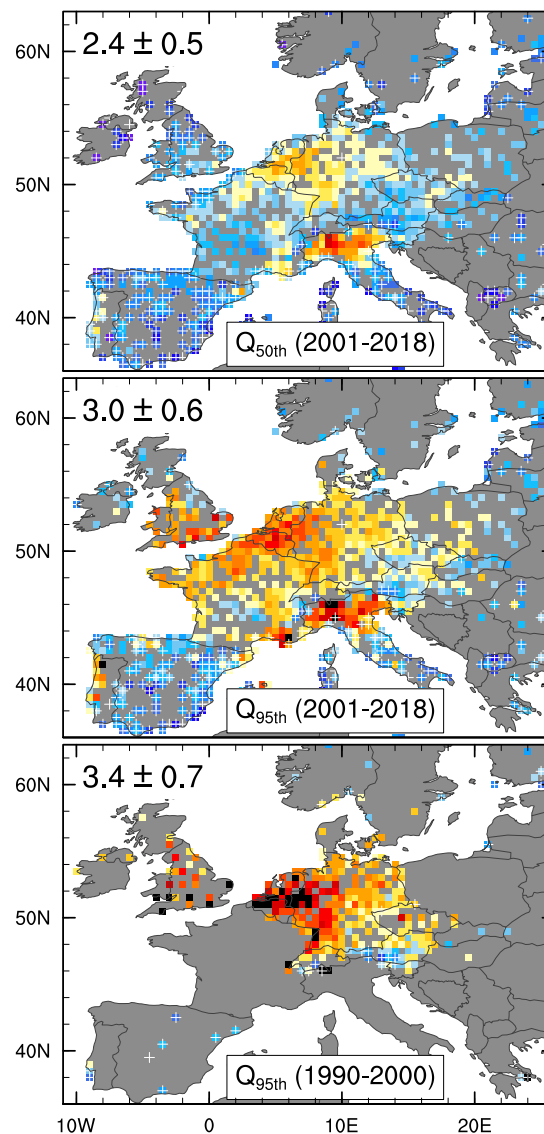

(b) FIXDEPV

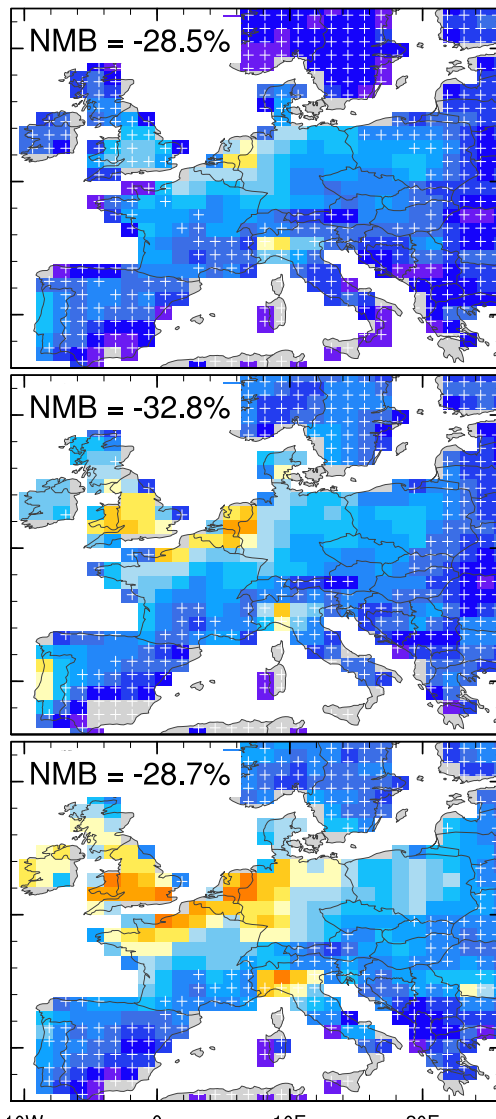

(c) IAVDEPV

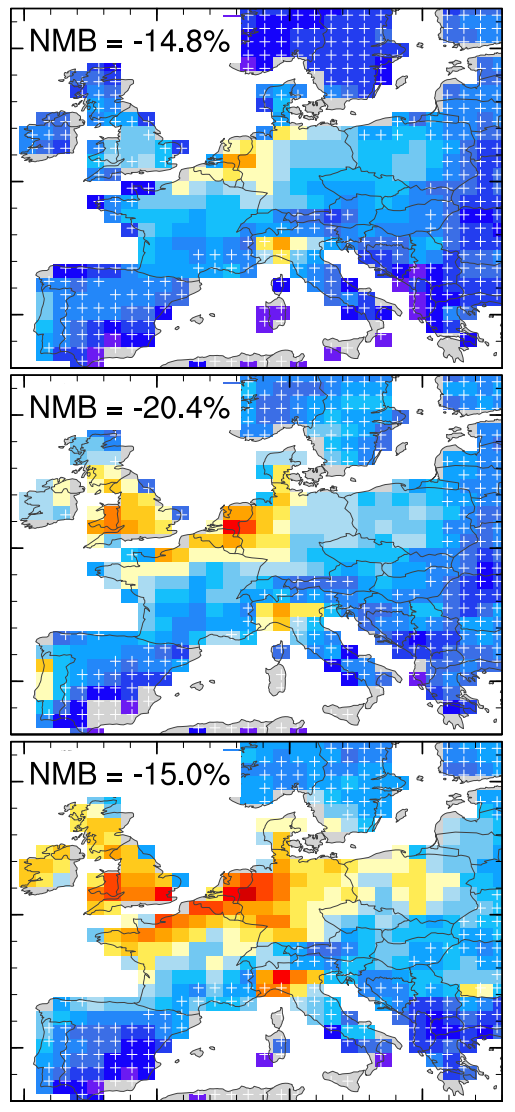

(d) IAVDEPV_FIXEM

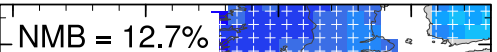

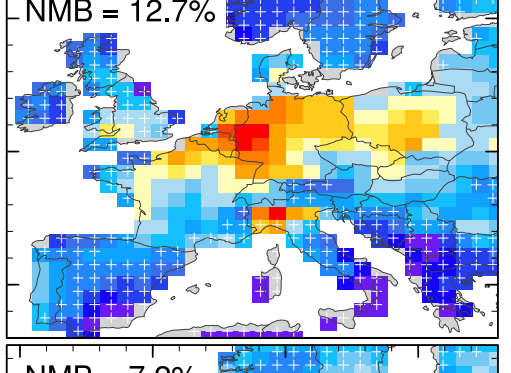

NMB $=7.2 \%$ क
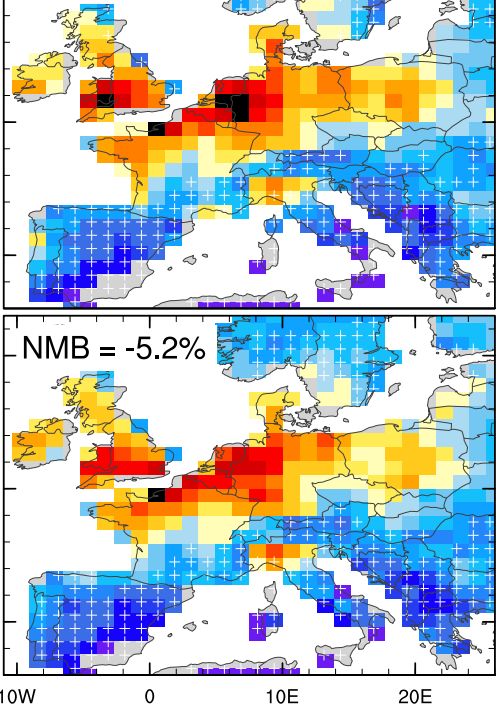

$20 \mathrm{E}$

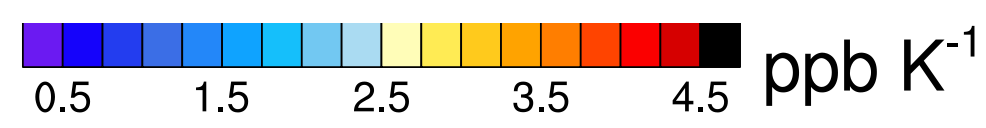

Figure 6. Ecosystem-atmosphere interactions exacerbate climate penalty on ozone extremes. (Top) Maps of median MDA8 ozone sensitivities to daily maximum temperature during July and August of 2001-2018 from observations $\left(0.5^{\circ} \mathrm{x} 0.5^{\circ}\right)$ and model simulations $\left(1^{\circ} \times 1^{\circ}\right)$ with constant $\mathrm{V}_{d, O 3}$ (FIXDEPV), with $\mathrm{V}_{d, O 3}$ coupled to vegetation and climate (IAVDEPV), and with varying $\mathrm{V}_{d, O 3}$ but fixed-1980 emissions (IAVDEPV_FIXEM). (Middle) Same as the top panels, but for the 95th percentile. (Bottom) Same as the middle panels, but for the 1990-2000 period. Stippling indicate the grid cells where the quantile regression coefficients (r) are lower than 0.5. Numbers on the topleft corner of each graph are the mean values and normalized mean biases (NMB; in percent) for the grid cells with $\mathrm{r} \geq 0.5$ in the land area bounded by $5^{\circ} \mathrm{W}-25^{\circ} \mathrm{E}$ and $40^{\circ}-55^{\circ} \mathrm{N}$. 
1978-2000 JJA Hohenpeissenberg

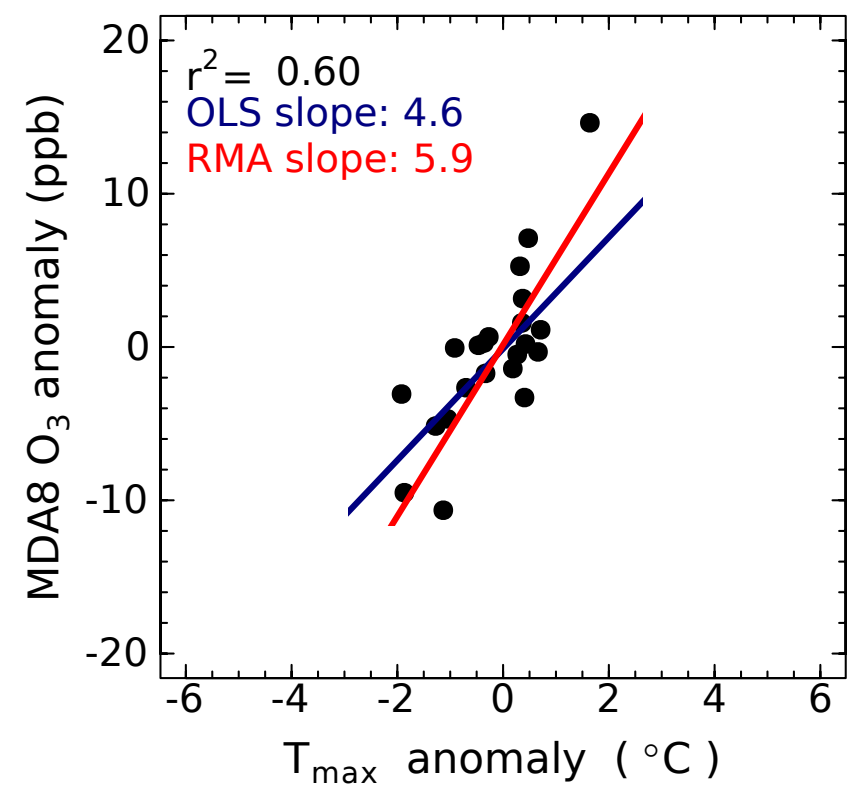

2001-2018 JJA Hohenpeissenberg

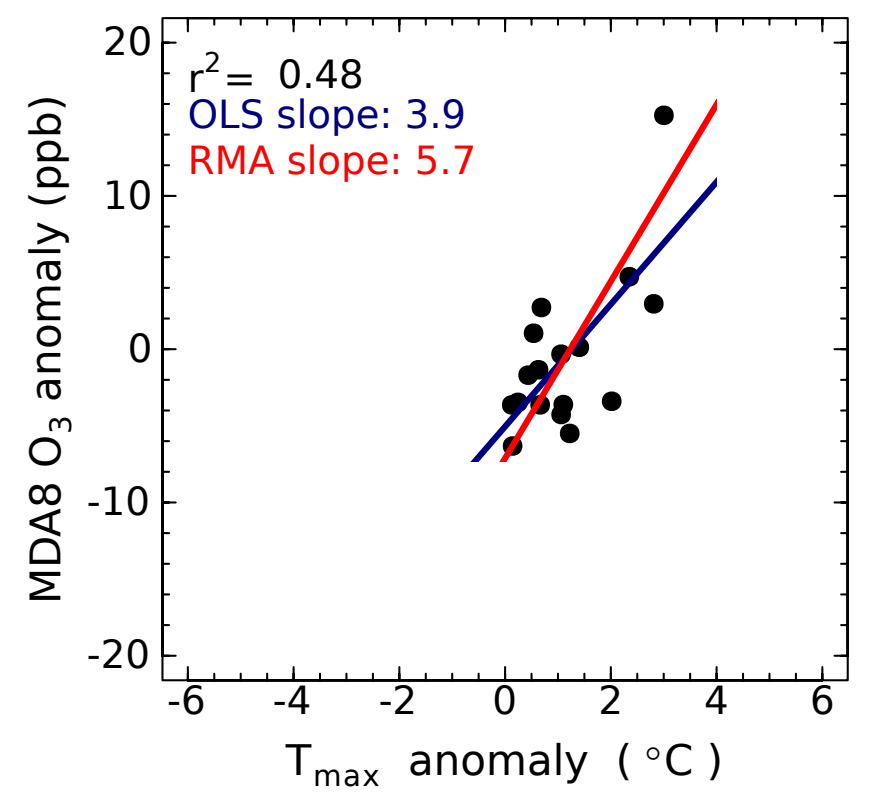

1978-2000 JJA Zugspitze

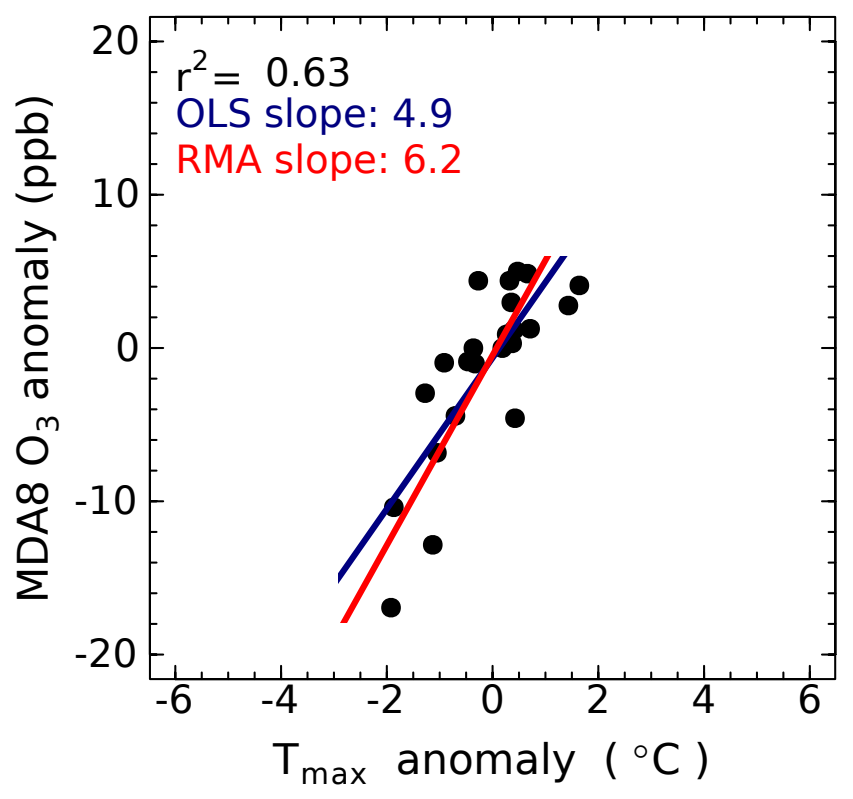

2001-2010 JJA Zugspitze

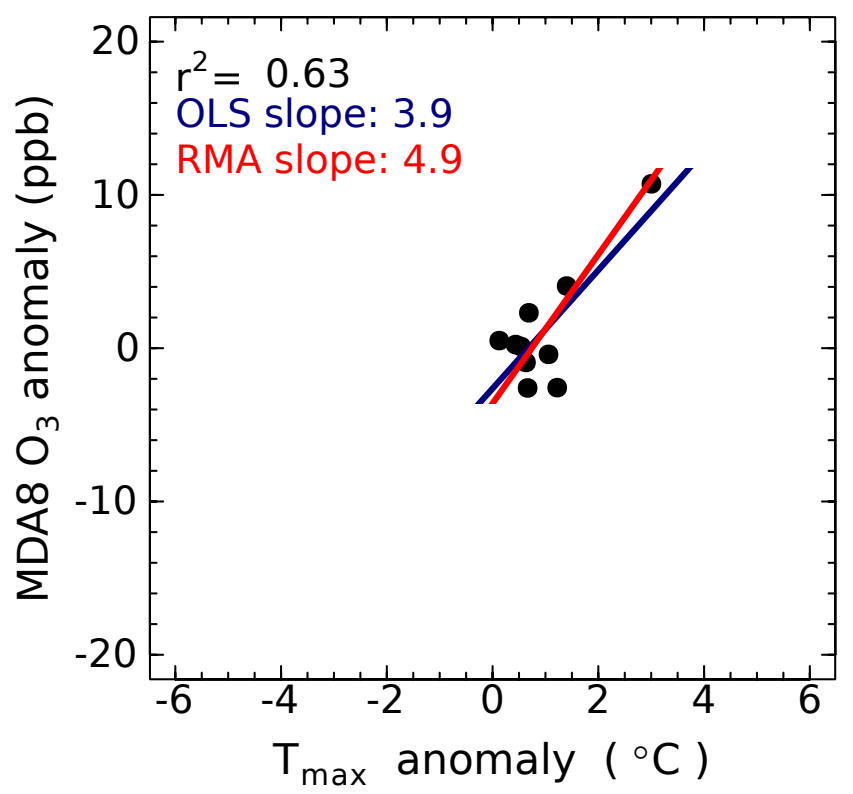

. Extended Data Fig.1 | Ozone-temperature relationships. Scatter plots of observed June-August mean MDA8 ozone anomalies at Hohenpeissenberg and Zugspitze and observed June-August mean $\mathrm{T}_{\max }$ anomalies (relative to 1980-2000) averaged over 42-53N and 0-15E, with linear regression fits using the Ordinary Least Squares (OLS, blue) and Reduced Major Axis (RMA, red) methods, respectively. The OLS regression slopes are reported in Fig.1 in the main article. 
a

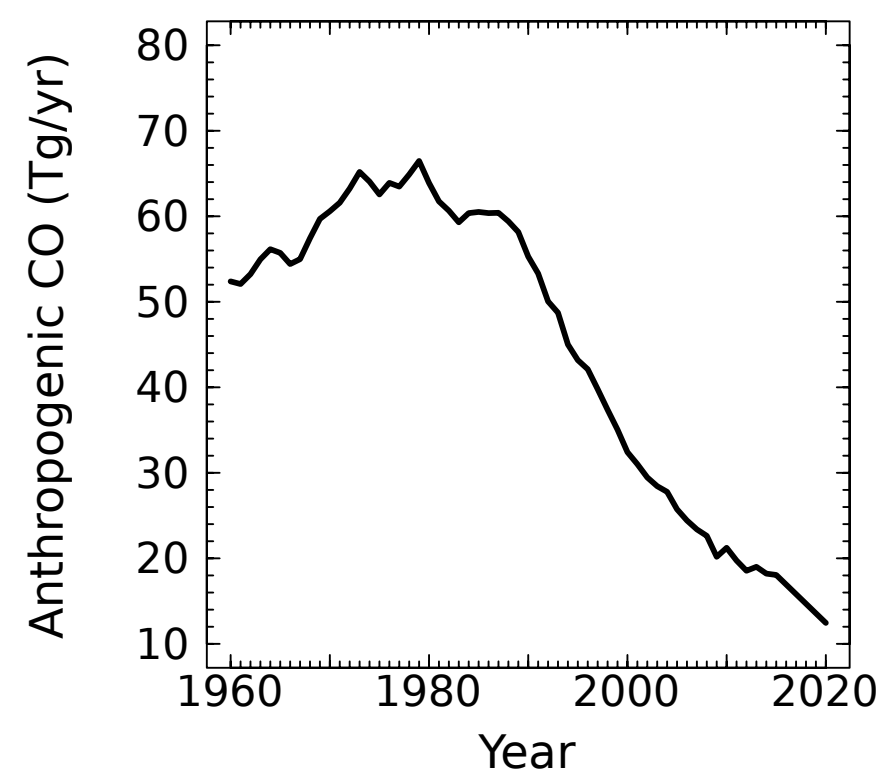

C

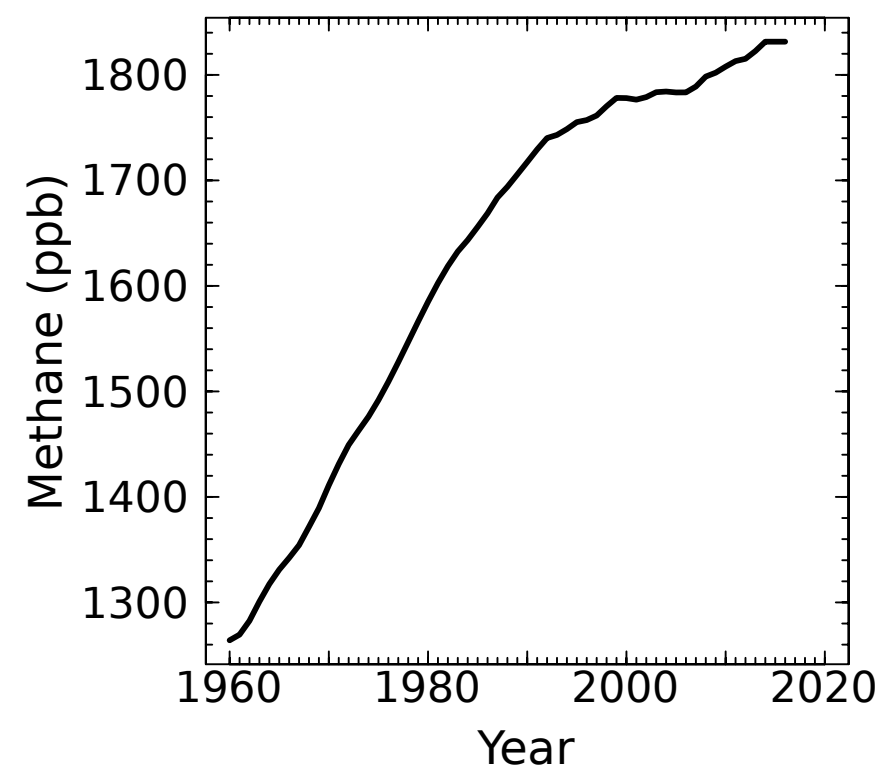

b

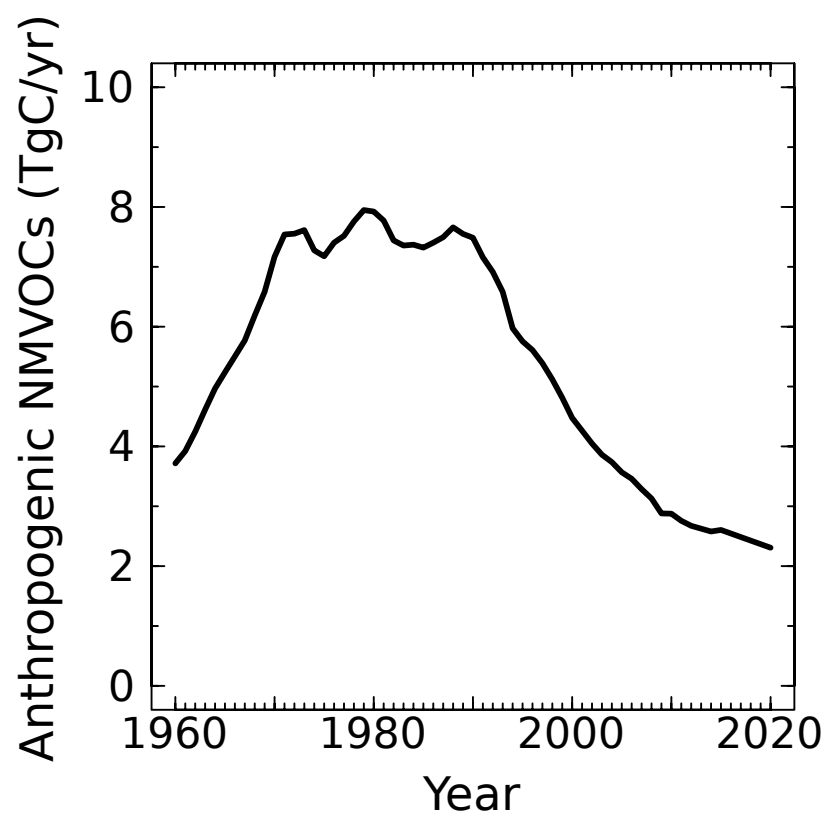

d

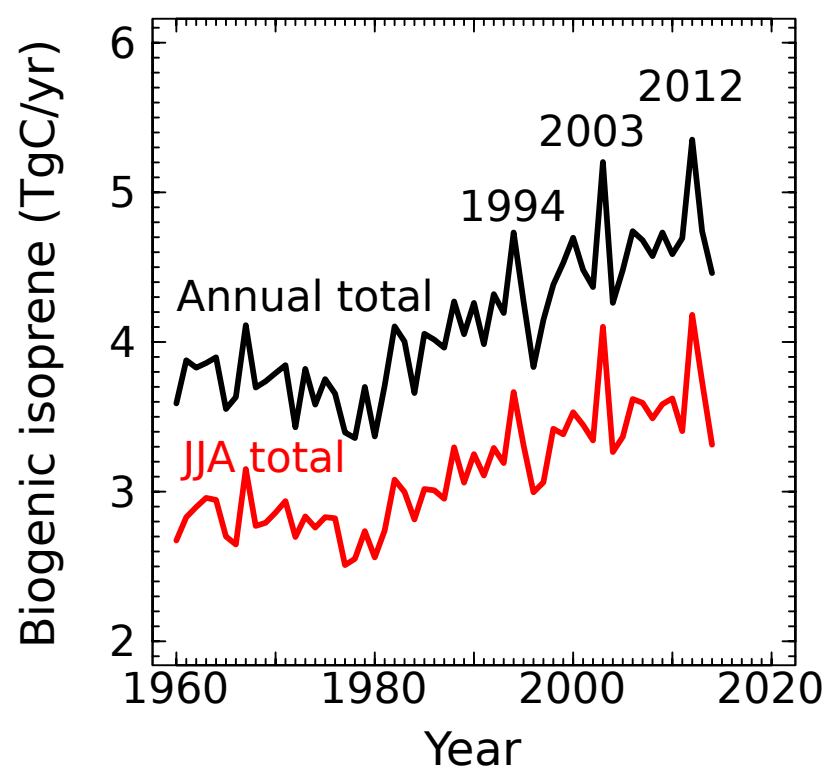

. Extended Data Fig.2 | Emission trends. (a-b) Trends in anthropogenic emissions of carbon monoxide and non-methane volatile organic compounds (NMVOC) in Europe (40-60N; 10W-25E) from the CMIP6 historical dataset used by the model. (c) Observed trends in global average methane mixing ratios used by the model. (d) Model estimated trends in biogenic isoprene emissions over Europe (40-60N;10W-25E). 


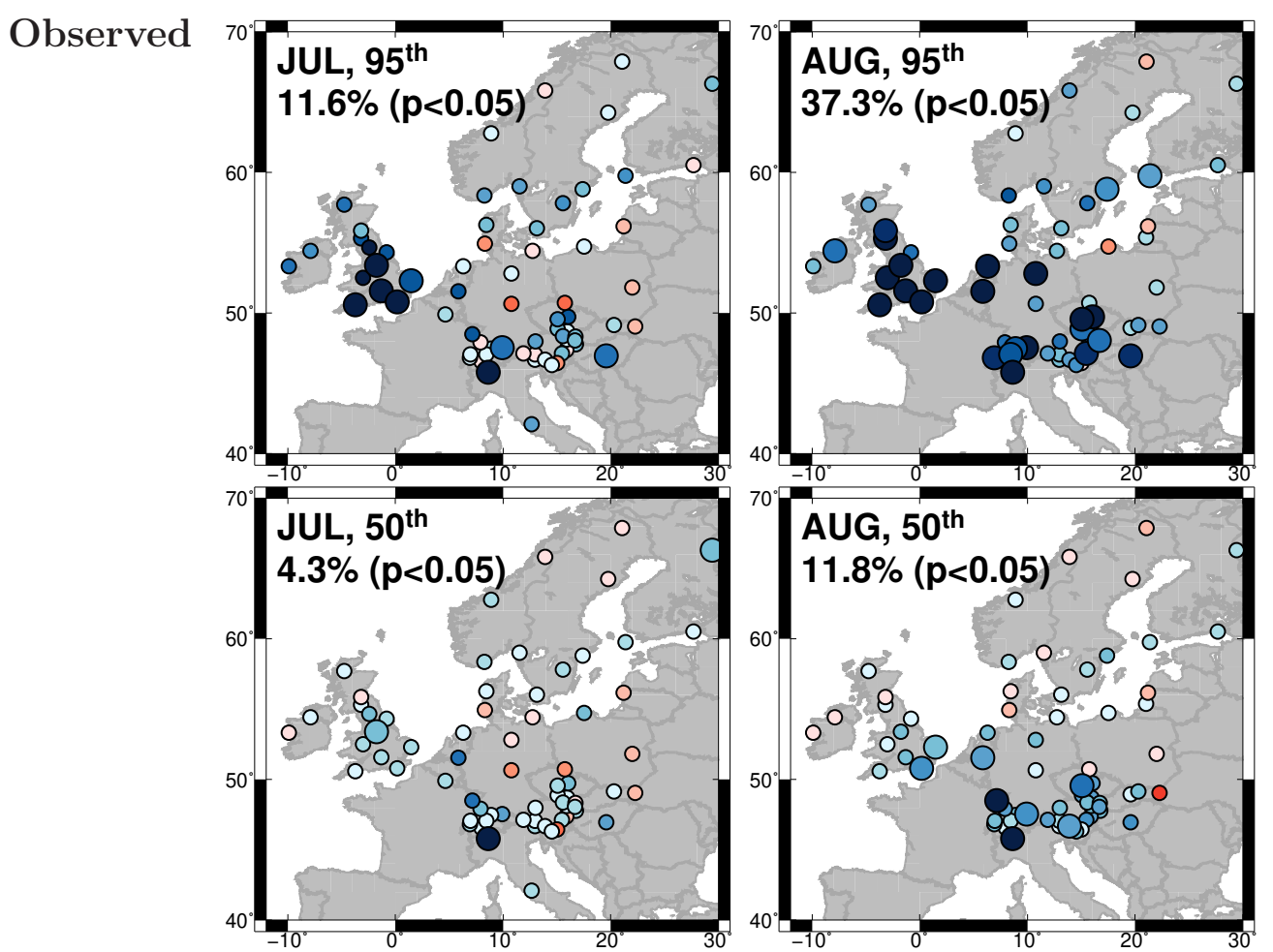

Model
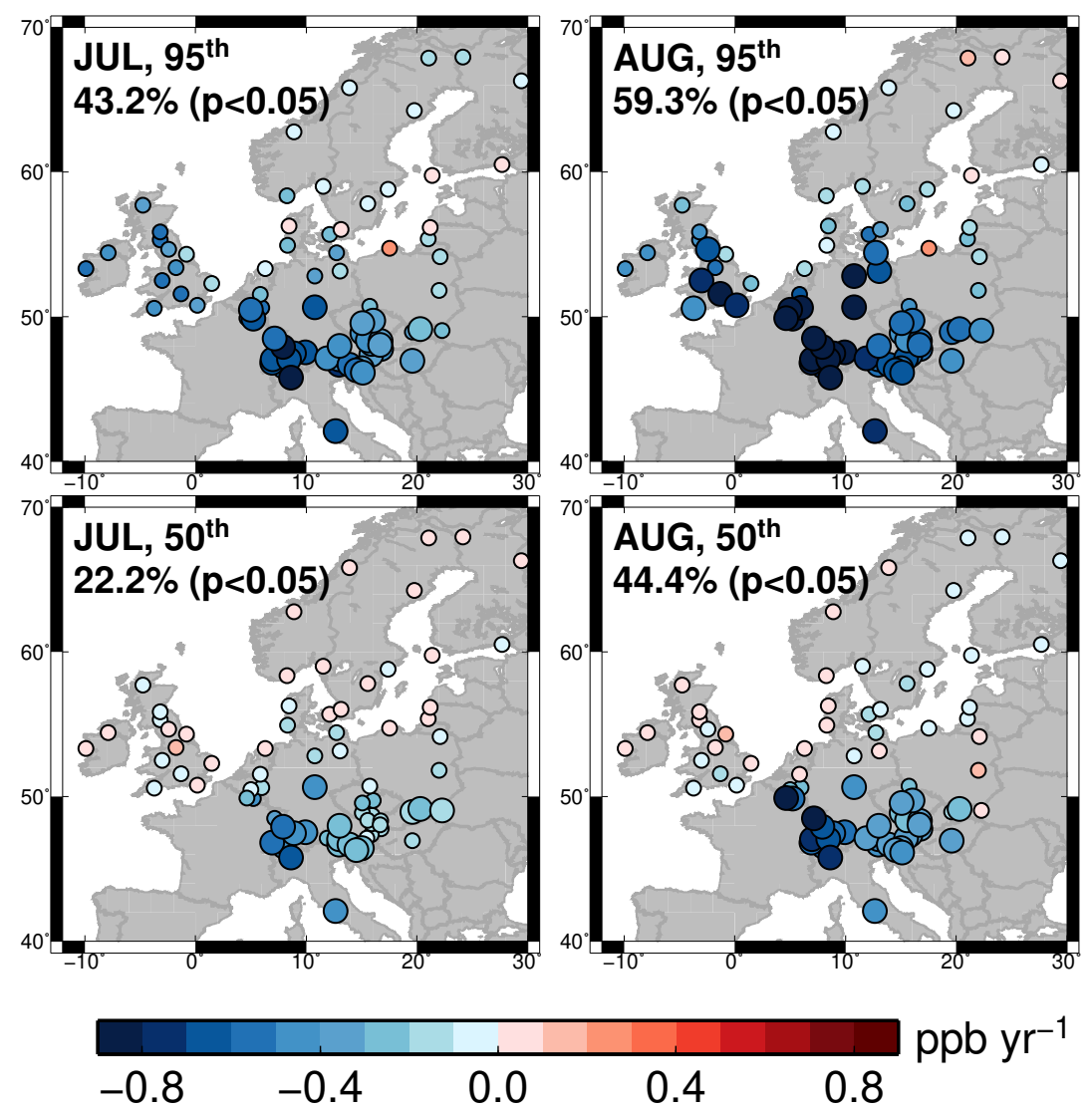

. Extended Data Fig.3 | Surface ozone trends in Europe. Maps of the 1990-2015 trends in daily MDA8 ozone for the 95th and 50th percentiles in July and August from observations (top) and IAVDEPV simulations (bottom). Results are shown for EMEP sites with at least 20 years of data, with larger circles indicating sites with significant ozone trends $(\mathrm{p}<0.05)$. The percentage of sites with significant trends are reported at the top-left corner of each graph. 

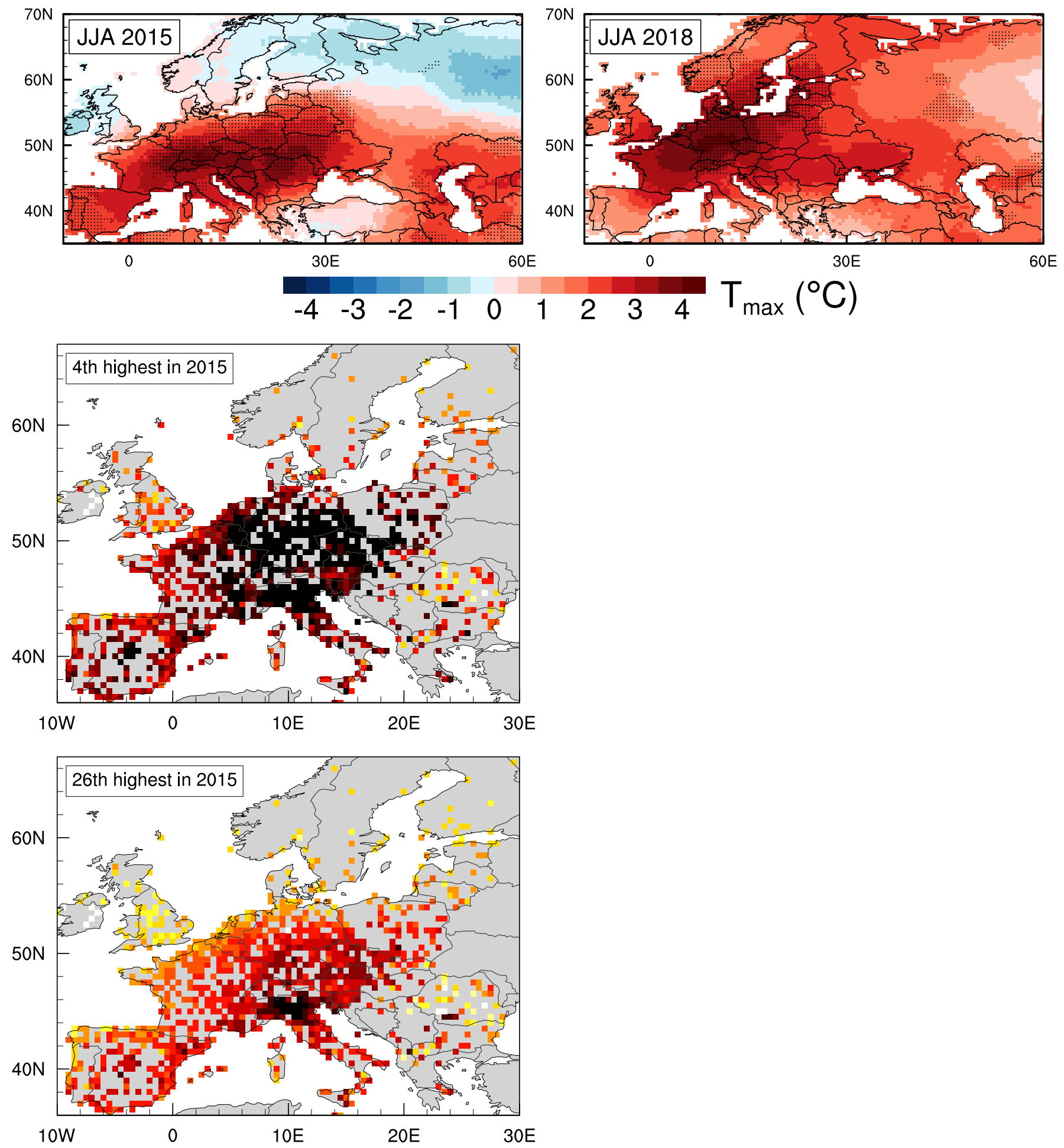

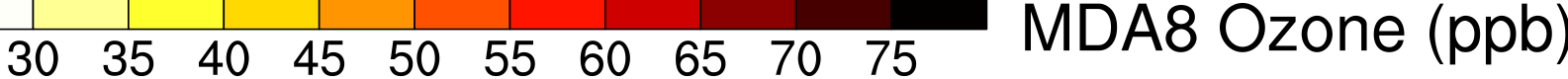

Extended Data Fig.4 | Ozone pollution during the 2015 and 2018 heat waves. (Top) Maps of observed daily maximum temperature anomalies in June-August of 2015 and 2018 relative to the base period 1961-1990, with dots indicating area in drought (SPEI06 <-1). (Middle) The annual 4th highest MDA8 ozone concentrations from all available observations gridded at $0.5^{\circ}$ resolution, with values above 70 ppb implying an exceedance of the health limit set by the U.S. Environmental Protection Agency. (Bottom) The annual 26th highest MDA8 ozone concentrations, with values above $60 \mathrm{ppb}$ implying an exceedance of the health limit set by the European Union. 

(a) SPEI06
(b) SPEI02
(c) SPEI01
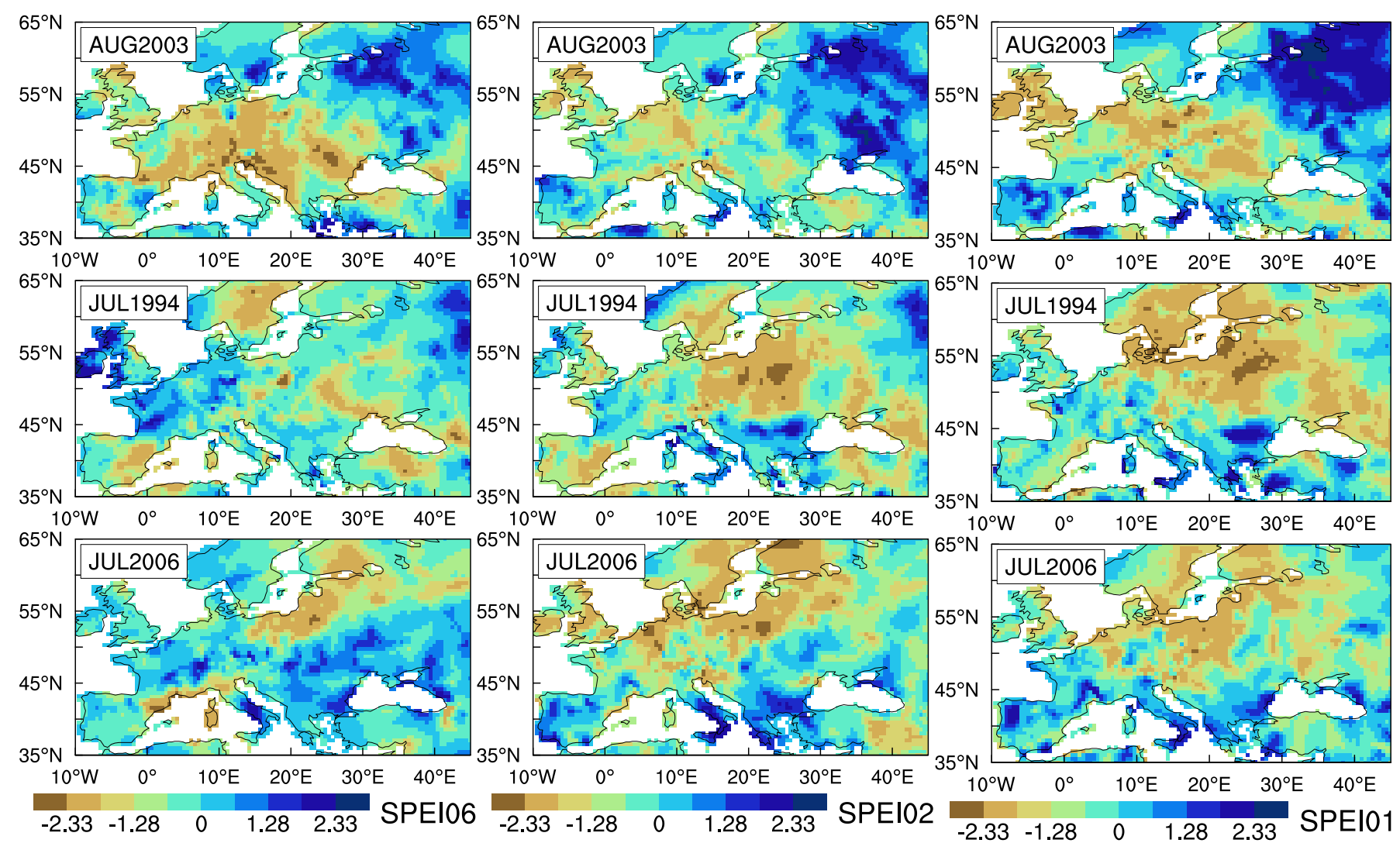

Extended Data Fig.5 | Drought conditions. The Standardised Precipitation-Evapotranspiration Index (SPEI) integrated over the preceding 6 months, 2 months, and 1 month for August 2003, July 1994 and July 2006. 
(a) 2000-2015 average
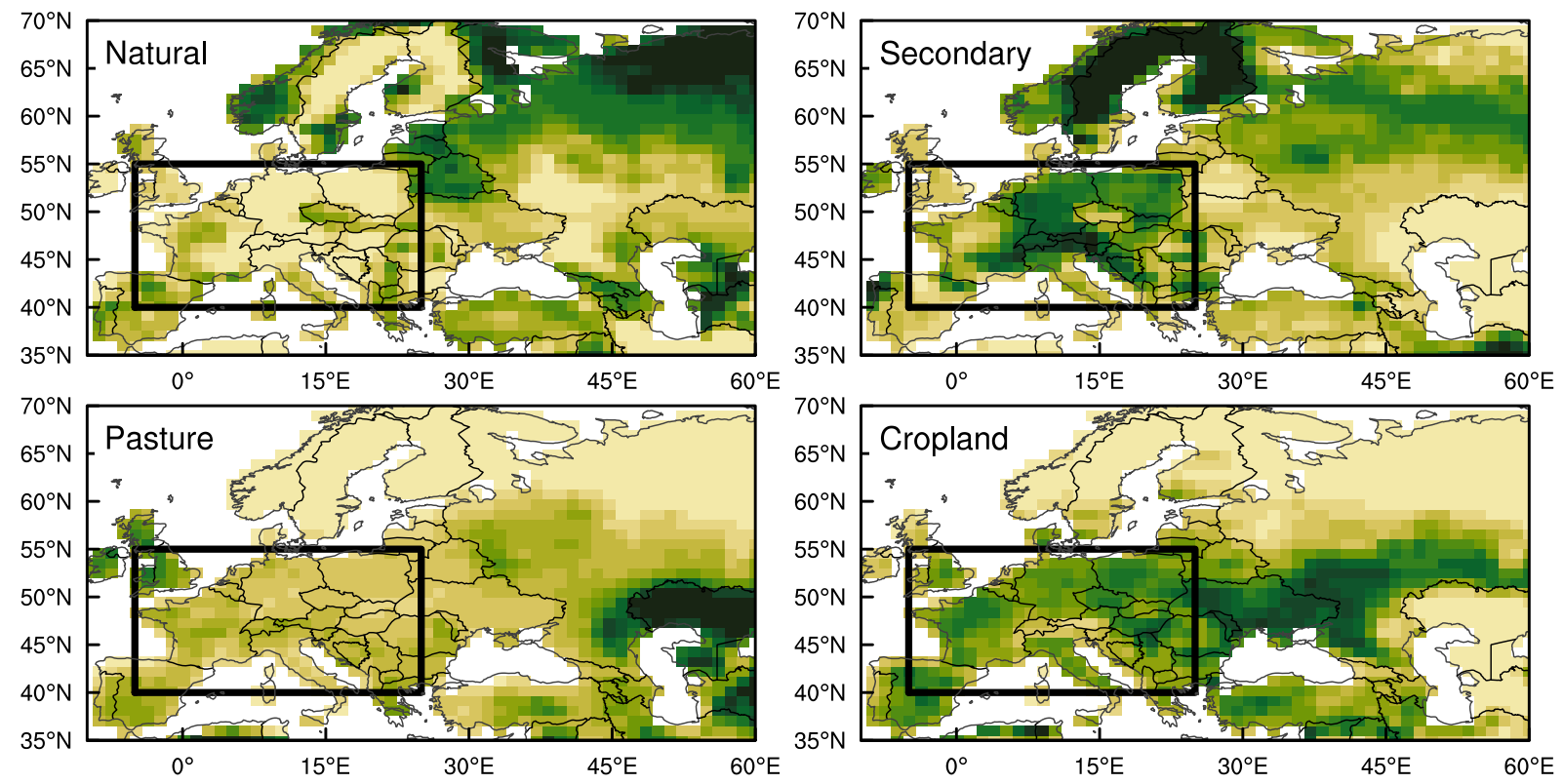

$\begin{array}{llllllllllllllll}\text { Fraction } & 0 & 0.1 & 0.2 & 0.3 & 0.4 & 0.5 & 0.6 & 0.7\end{array}$

(b) 2000s minus 1960s
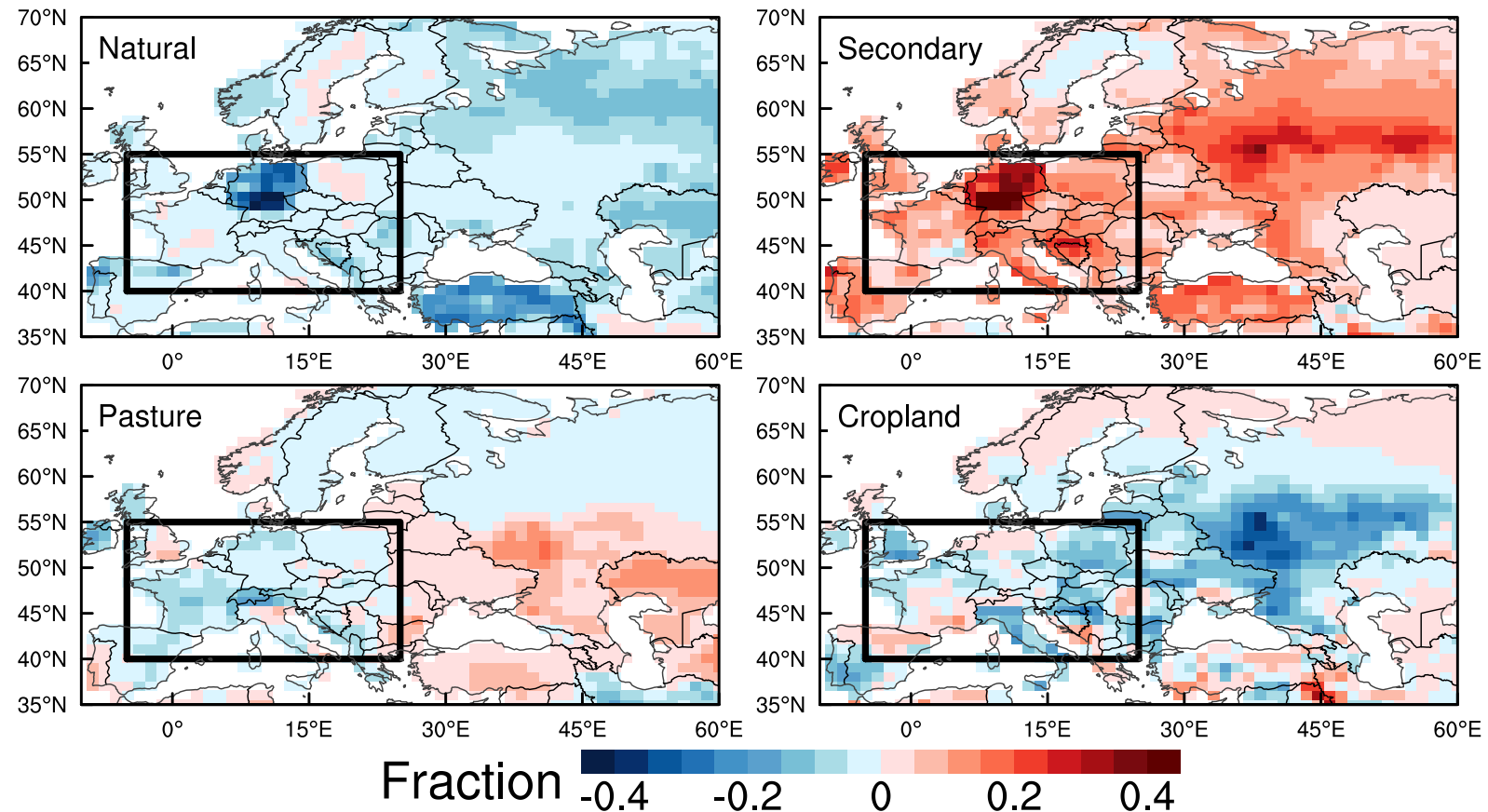

Extended Data Fig.6 | Land use. (a) Fraction of the four land use categories in each grid cell averaged over 2000-2015: Natural forests (lands undisturbed by human activities), secondary vegetation (lands harvested at least once, including managed forests and abandoned cropland and pasture), croplands, and pastures. (b) Changes in 2000-2015 relative to the 1960s. The box denotes the area used for averaging in Extended Data Fig.6. 

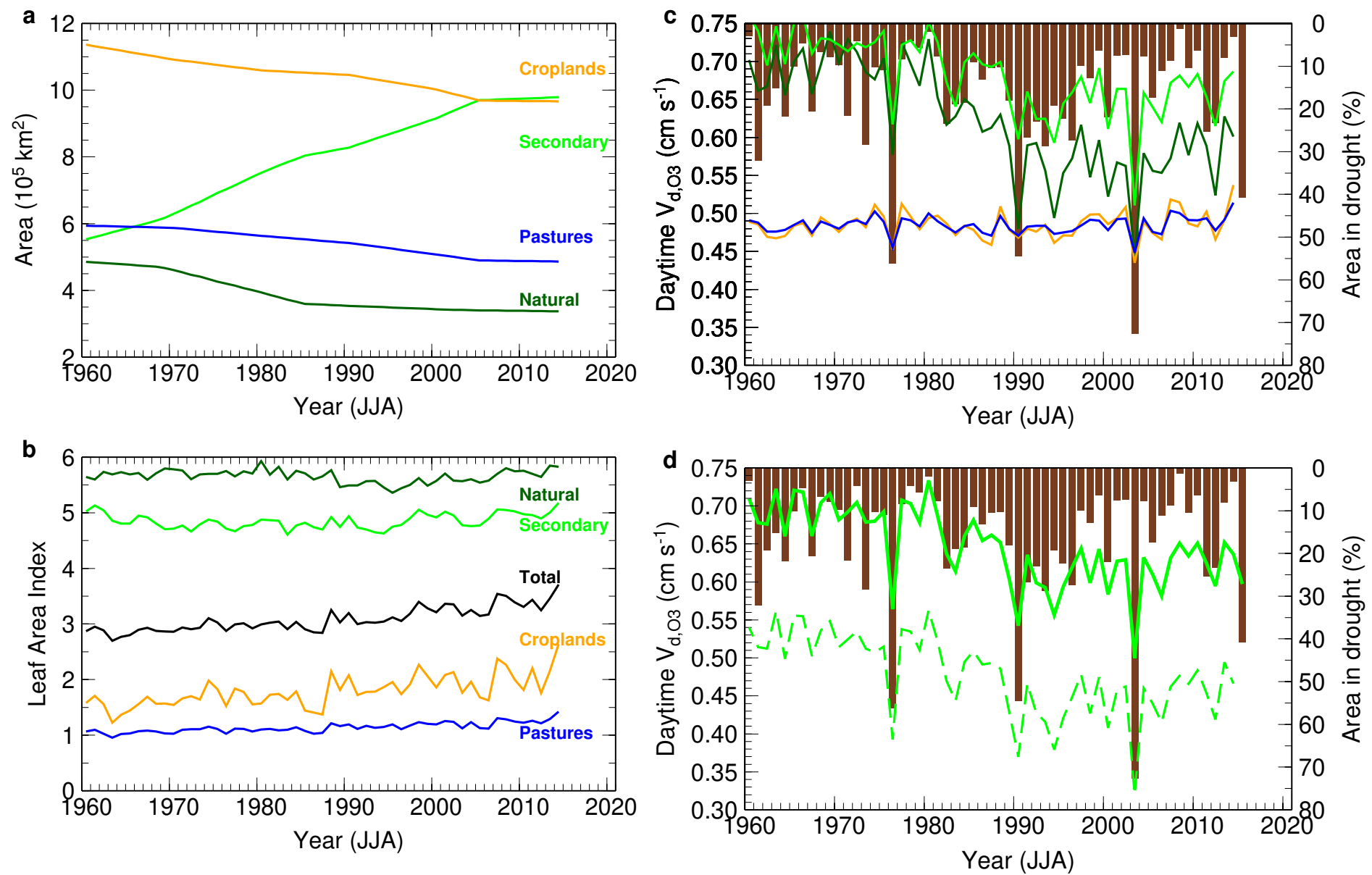

. Extended Data Fig.7 | Declining ozone removal by vegetation due to stomatal closure under soil drying as opposed to land use changes. (a) Evolution of land use over western Europe (5W-25E and 40-55N): Natural forests (dark green), secondary vegetation (green), croplands (orange), and pastures (blue). (b) Area-weighted leaf area indices. (c) Area-weighted daytime ozone deposition velocities. (d) Total (solid green lines) and stomatal (dashed green lines) ozone deposition velocities averaged over natural and secondary vegetation land areas over western Europe. The vertical bars show the percentage of land area in drought with SPEI06 <-1 (right axis). 
a
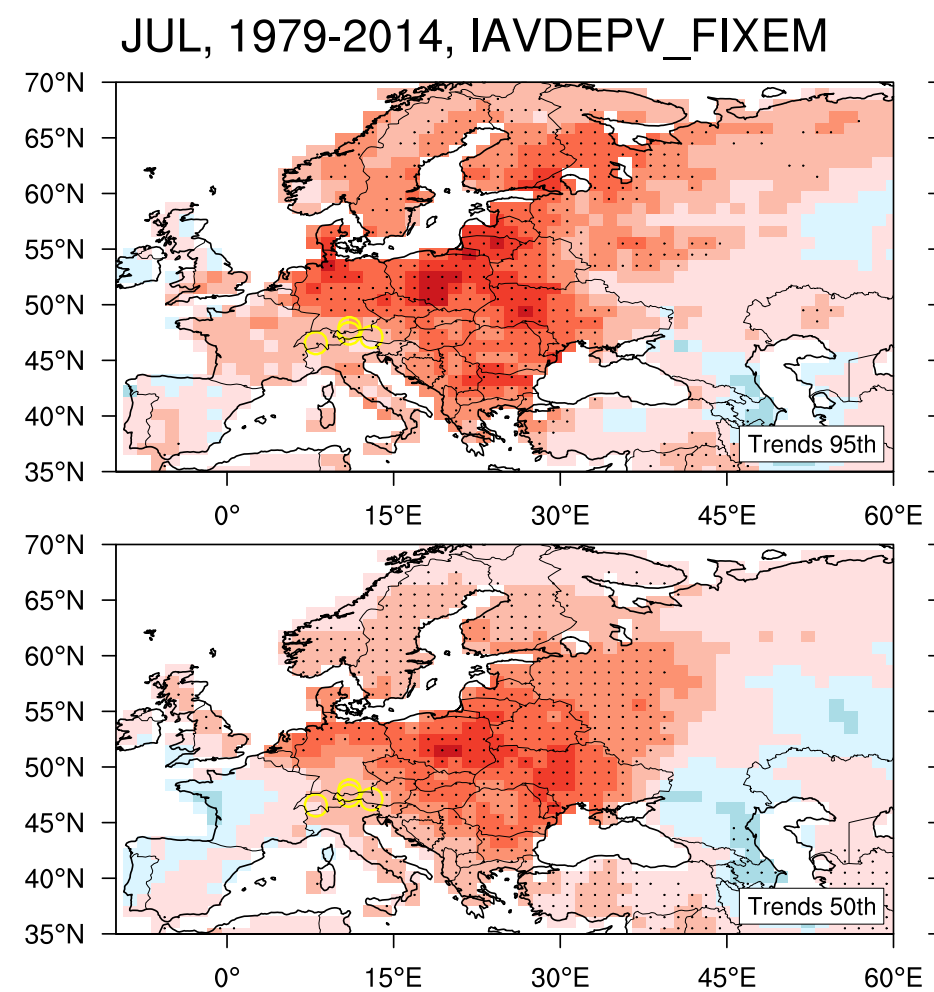

b
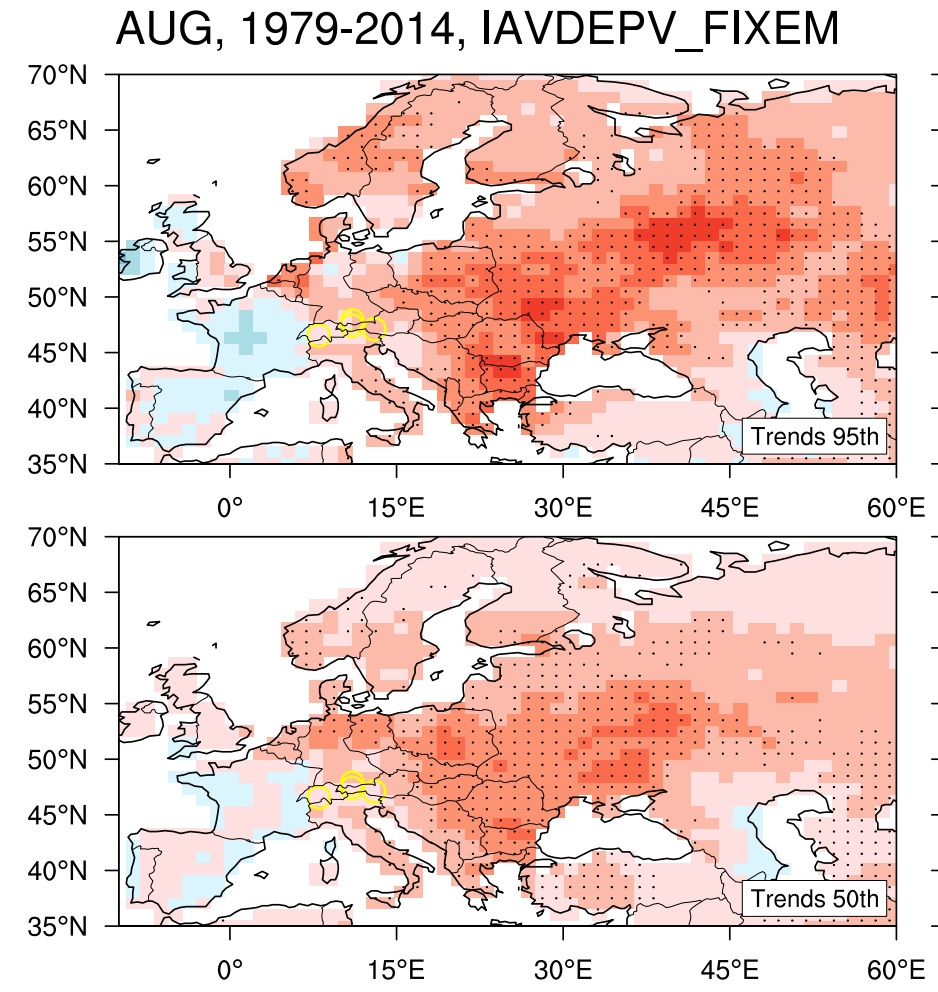

JUL, 1990-2014, IAVDEPV_FIXEM
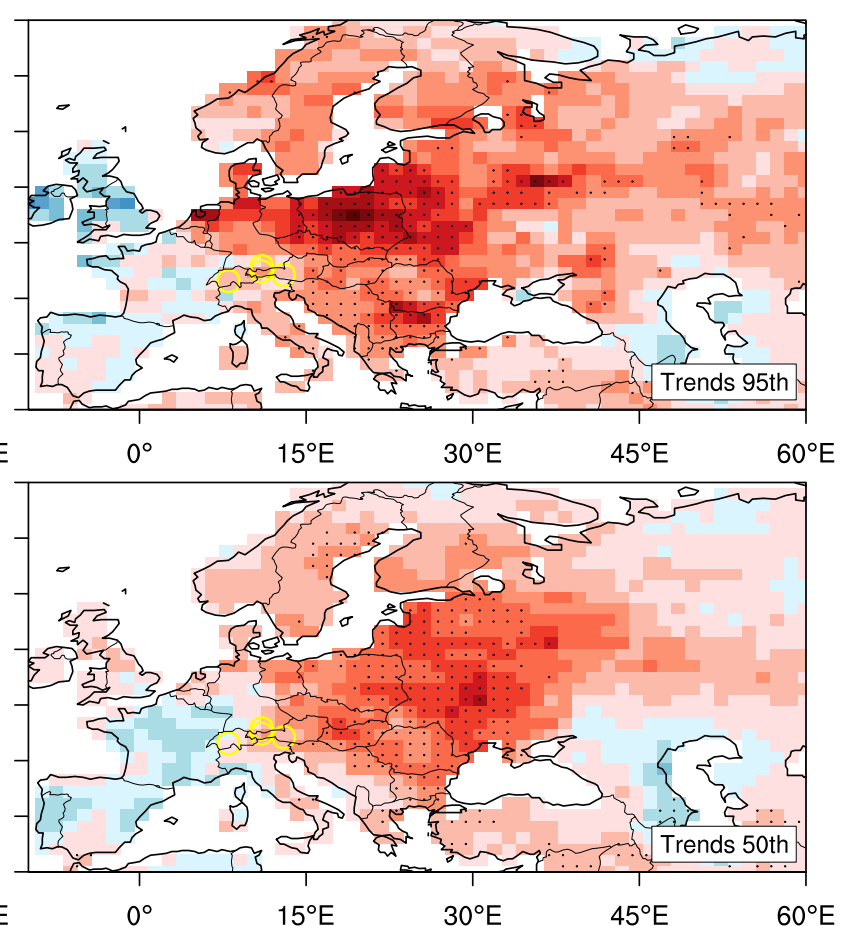

AUG, 1990-2014, IAVDEPV FIXEM

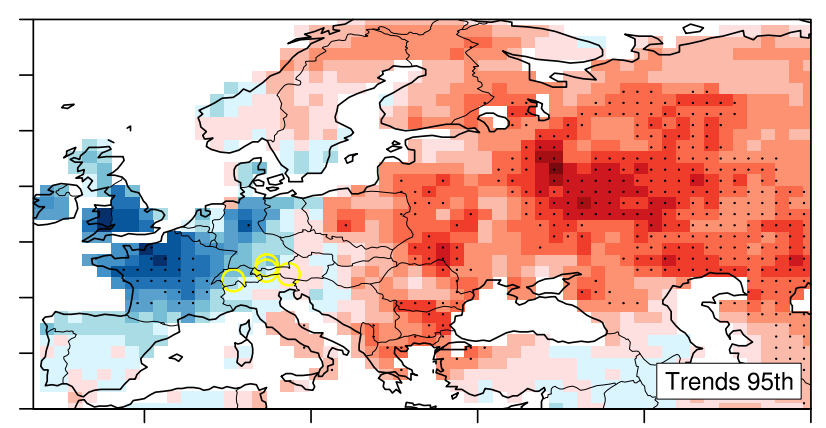

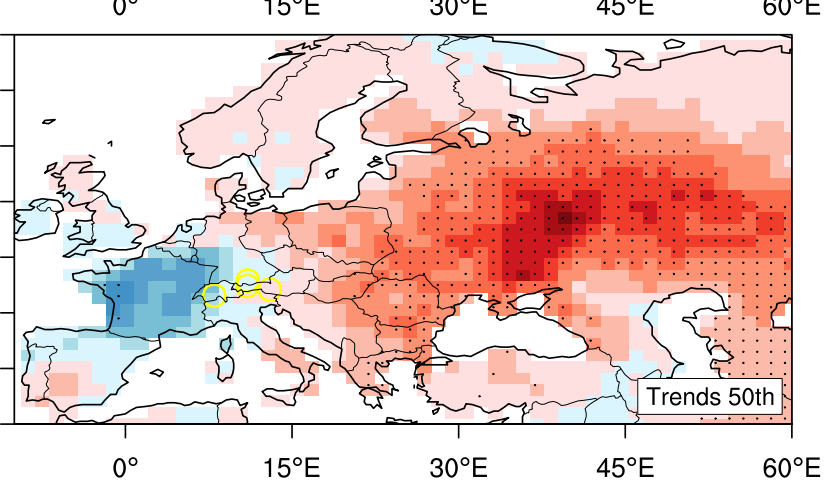

$60^{\circ} \mathrm{E}$

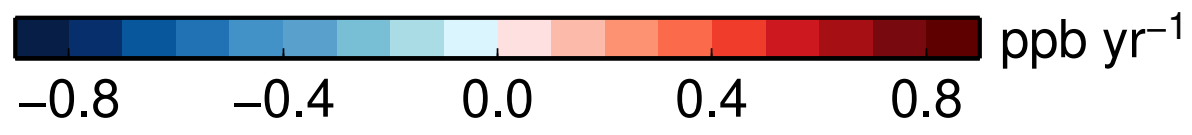

Extended Data Fig.8 | Climate-driven trends in surface ozone over Europe. Maps of the 1979-2014 and 1990-2014 trends in the 95th and 50th percentile MDA8 ozone concentrations for July and August, simulated by the IAVDEPV_FIXEM experiment with anthropogenic emissions held constant at 1980 levels. Stippling denotes areas where the change is statistically significant at the $95 \%$ confidence level $(\mathrm{p}<0.05)$. 

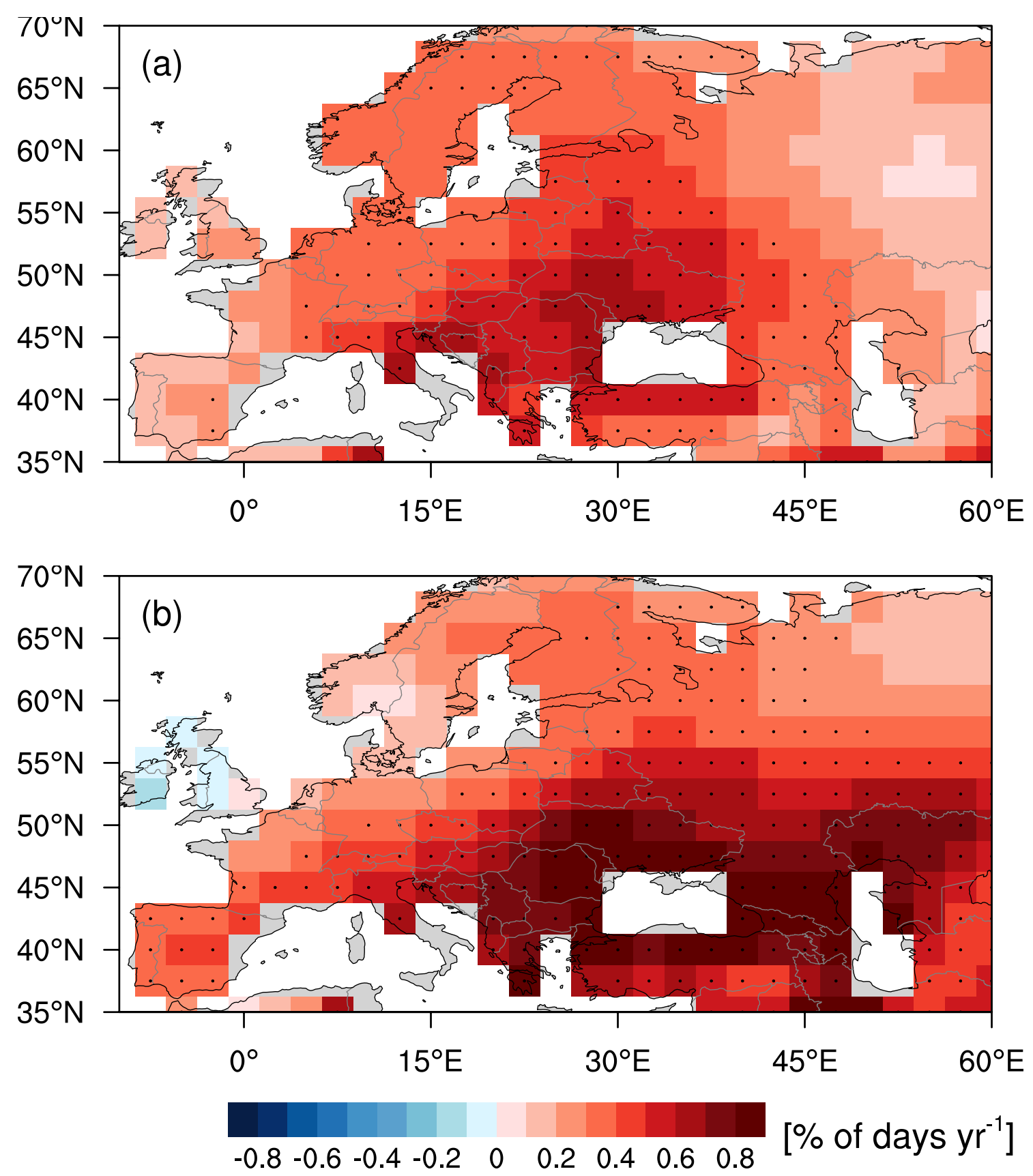

. Extended Data Fig.9 | Observed trends in hot extremes over Europe. Maps of the 1979-2019 trends in the frequency of warm days (i.e., those above the 90th percentile for the base period 1961-1990) in July (a) and August (b), respectively, obtained from the Global Land-Based Datasets for Monitoring Climate Extremes (Methods). Stippling denotes areas where the change is statistically significant ( $\mathrm{p} \leq$ $0.05)$. 


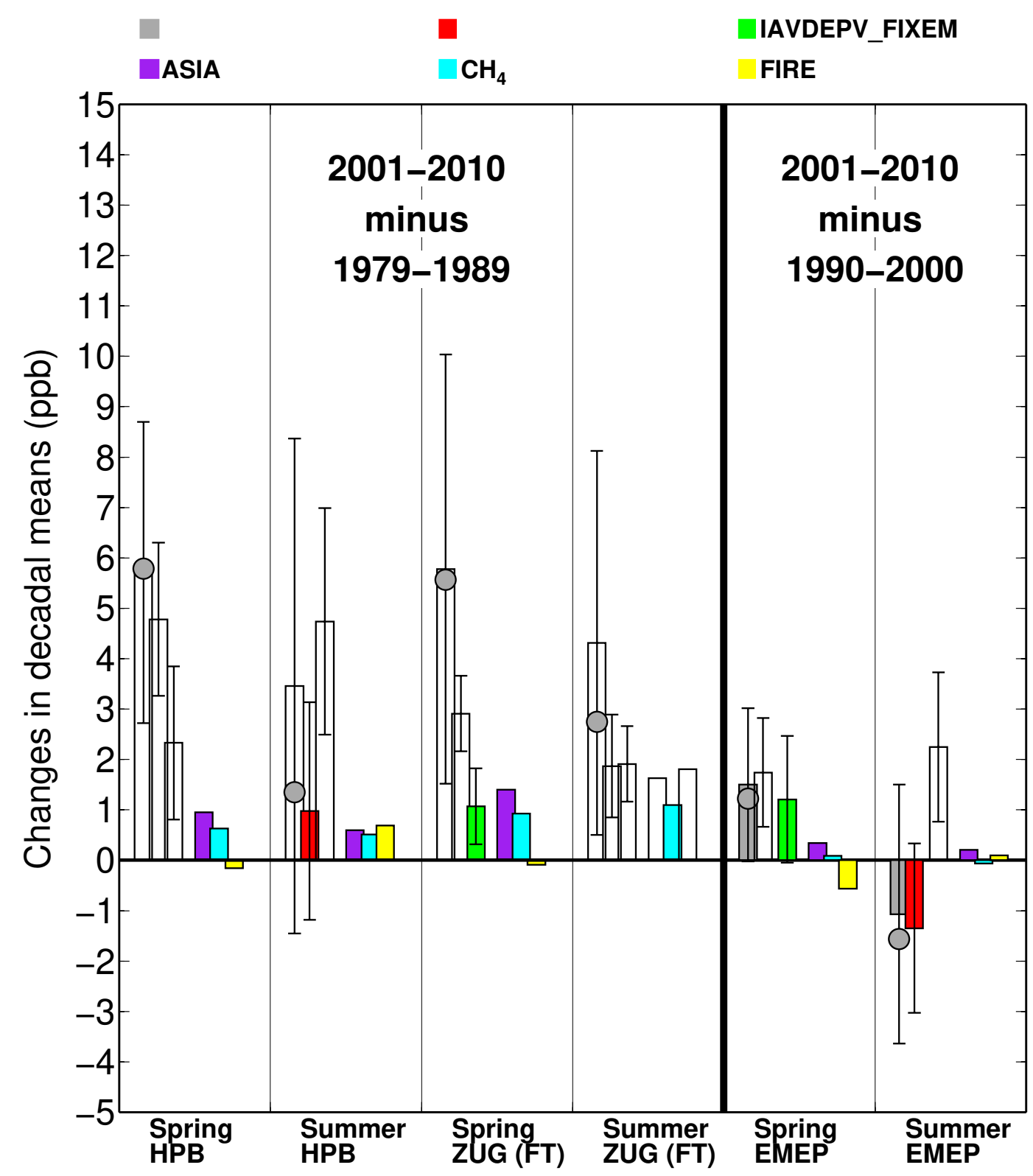

. Extended Data Fig.10 | Drivers of decadal mean ozone trends in Europe. Changes in decadal mean ozone levels during spring (March-May) and summer (June-August) from 1979-1989 to 2001-2010 as inferred from surface observations at Hohenpeissenberg (985 m altitude, MDA8 values), from alpine observations at Zugspitze (2962 m altitude, 24-hour mean), and from 1990-2000 to 2001-2010 at 52 EMEP sites over $40 \mathrm{~N}-55 \mathrm{~N}$ with continuous observations (MDA8 values). For observations, both changes in decadal mean (gray bars) and median (circles) values are shown, with the error bars indicating the range of the mean change at the $95 \%$ confidence level. Model results are shown for the BASE and IAVDEPV_FIXEM experiments and the contributions from changes in Asian anthropogenic emissions, global methane concentrations, and wildfire emissions. For comparisons with free tropospheric observations at the Zugspitze, model results are sampled at $700 \mathrm{hPa}$. 